\title{
Partidos, governo e Legislativo nas disputas do Orçamento Participativo: uma análise comparativa
}

\author{
Luciana Andressa Martins de Souza ${ }^{1}$ (iD
}

\begin{abstract}
Este artigo amplia a discussão acerca das disputas entre o Orçamento Participativo (OP), os partidos e os atores políticos locais, ao apresentar uma análise sistemática e diacrônica dos impactos da composição de forças dos partidos governistas e oposicionistas, delineadas no âmbito da arena eleitoral, sobre a adoção, durabilidade, interrupção e o fim dessa inovação democrática, assim como sobre os seus distintos graus de institucionalização. Para tanto, analisamos três pares contrafactuais de municípios com características majoritariamente semelhantes, a saber: São Carlos e Piracicaba; Rio Claro e Leme; Matão e Sertãozinho. Esses pares se diferenciam pelo partido que esteve à frente da iniciativa do OP (PT e outros partidos). Os resultados revelam um universo pouco explorado e passível de ser replicado em outros contextos, contribuindo tanto para a ampliação do debate acerca do papel do Legislativo no grau de institucionalização de instituições participativas quanto para o aprimoramento dessa agenda de pesquisa.
\end{abstract}

Palavras-chave: Orçamento Participativo (OP); partidos políticos; Executivo; Legislativo; governos locais

\section{Introdução}

O Orçamento Participativo (OP) pode basicamente ser definido como um processo participativo por meio do qual qualquer cidadão pode contribuir em decisões, ainda que parciais, do orçamento municipal ${ }^{3}$. O caso de Porto Alegre, um dos pioneiros e mais duradouros, tornou-se referência de inovação democrática, especialmente após ser reconhecido pela Organização das Nações Unidas (ONU), em 1996, por ocasião da Conferência de Istambul, Habitat II, como uma das 40 melhores práticas de governança

\footnotetext{
1 Universidade Federal do Espírito Santo. Programa de Pós-Graduação em Ciências Sociais (PPGCS-Ufes); Núcleo Participação e Democracia (Nupad-Ufes). Vitória (ES), Brasil. Núcleo Democracia e Ação Coletiva (NDAC) - Centro Brasileiro de Análise e Planejamento (Cebrap). São Paulo (SP), Brasil. E-mail: <lu.ufscar@hotmail.com>.

2 Este artigo é resultado da pesquisa de pós-doutorado desenvolvida no Núcleo Democracia e Ação Coletiva do Centro Brasileiro de Análise e Planejamento (NDAC-Cebrap). Agradeço à Fapesp pelo apoio obtido no âmbito da pesquisa de pós-doutorado (Processo Fapesp 12/21434-6).

3 Para maiores informações sobre essa questão, ver: Goldfrank (2006); Pires e Pineda Nebot (2008); Sintomer, Herzberg e Röcke (2008, 2012); Lüchmann (2014).
} 
urbana do mundo, legitimação que intensificou a sua difusão para outros municípios, níveis de governo e países ${ }^{4}$.

Atualmente se observa o paradoxo a seguir. Por um lado, o OP é considerado uma inovação democrática do mundo contemporâneo e estima-se que existam entre 795 e 1.469 episódios em diferentes partes do mundo (Sintomer, Herzberg e Röcke, 2012)5. Por outro, em que pese a rápida difusão do OP em municípios brasileiros ao longo dos anos 1990 e início dos anos $2000^{6}$, nos últimos tempos estima-se haver crescimento no número de casos de abandono da prática no Brasil (Spada, 2014). Esse fenômeno não é recente. No final dos anos 1990 e início dos anos 2000, Fedozzi (2008, p. 14) sublinhou que foi significativo o número de casos de OPs interrompidos devido à mudança de partido do prefeito ou até mesmo antes de serem concluídos os quatro anos de mandato. No estado de São Paulo, por exemplo, foram implementadas 23 experiências de OP entre 1997 e 2000 , sendo que 12 dessas iniciativas se mantiveram e 11 foram interrompidas na gestão subsequente (Serafim e Teixeira, 2006).

A "vontade política", por parte dos prefeitos, de adotar o OP aparece como variável proeminente no universo da política institucional, capaz de explicar a longevidade dessa instituição participativa, ao lado da influência do "desenho institucional", observado por meio dos elementos organizacionais incorporados ao OP, bem como da existência de uma forte "tradição associativa" local (Lüchmann, 2002; Avritzer, 2003; Wampler, 2003; Borba e Lüchmann, 2007). Contudo, ela se restringe ao comprometimento do prefeito em dar continuidade a essa proposta, em que pese o progressivo desenvolvimento das análises sobre as disputas entre os prefeitos, vereadores e partidos políticos no âmbito dessa instituição participativa (Avritzer, 2009; Romão, 2011; Wampler, 2008; Souza, 2011).

Este artigo amplia a discussão acerca das disputas entre o OP, os partidos políticos e os atores políticos locais, ao apresentar uma análise sistemática e diacrônica dos impactos da composição de forças dos partidos governistas e oposicionistas, delineadas no âmbito da arena eleitoral, sobre a adoção, a durabilidade, a interrupção e o fim dessa inovação democrática, assim como sobre os seus distintos graus de institucionalização. Para tanto, analisamos três pares contrafactuais de municípios com características majoritariamente semelhantes, a saber: São Carlos e Piracicaba7; Rio Claro e Leme; Matão e Sertãozinho, os quais se diferenciam entre si pelo partido que esteve à frente da iniciativa do OP (PT e outros partidos), assim como pelos diferentes graus de institucionalização produzidos pelo OP. Partimos da hipótese de que a centralidade do OP, como estratégia

\footnotetext{
${ }^{4}$ Fora do Brasil, os municípios pioneiros na adoção do OP foram: Saint-Denis (França), Rosário (Argentina), Montevidéu (Uruguai), Barcelona (Espanha), Bruxelas (Bélgica), entre outros.

5 Para informações mais atualizadas sobre o universo de OPs no mundo, consultar o volume organizado por Dias, Enríquez e Júlio (2020), o qual apresenta informações de 71 autores sobre experiências de OPs desenvolvidas em 78 países.

${ }^{6}$ Embora não haja informações precisas sobre o universo do OP, logo após a sua adoção na capital gaúcha foram produzidos dados confiáveis para o período subsequente, entre 1997 e 2000, os quais apontavam cerca de 140 casos no Brasil (Ribeiro e Grazia, 2003).

7 Exceto o caso de Piracicaba, diferente dos demais, por apresentar histórico de significativa tradição associativa.
} 
eleitoral do partido, declina à medida que as alianças eleitorais se ampliam. Desse modo, o OP poderia constituir-se como forte estratégia eleitoral inicial para o partido, paulatinamente arrefecida em função da competição política.

Em estudo precedente, comparamos os municípios de São Carlos, Rio Claro e Matão, os quais tiveram experiências de OP com distintas durabilidades (interrompida, contínua e descontínua) em períodos administrados pelo PT e outros partidos aliados. Nos casos analisados, o argumento da "vontade política" poderia contribuir para explicar tanto a continuidade do OP em São Carlos, em razão da reeleição do PT, quanto a interrupção do OP em Rio Claro, graças à chegada ao poder, como sucessora do governo da coligação PT-PV, de uma administração contrária ao OP (PFL/DEM). Entretanto, essa variável isoladamente não foi capaz de se desdobrar, no que diz respeito a Matão, na explicação da decisão tomada pela administração petista de não levar a cabo essa proposta na segunda e na terceira gestões do partido ${ }^{8}$.

Desse modo, acrescentamos mais três municípios, aos pares (São Carlos e Piracicaba, Matão e Sertãozinho, Rio Claro e Leme), que tiveram as mesmas durabilidades das experiências de OP, desenvolvidas por outros partidos (PSDB, PFL/DEM e PTB), no intuito de testarmos o alcance do mecanismo institucional de composição de forças dos partidos no governo e na oposição, travados na arena eleitoral, na adoção, na durabilidade (ou não) e nos distintos níveis de institucionalização do OP (participativo, bifurcado e limitado). Por conseguinte, o desafio aqui presente reside em ampliar o espectro de casos a fim de serem incluídos outros partidos e coligações, excluindo-se o PT. Para tanto, valemo-nos do argumento segundo o qual a simples vontade política, por si só, não seria fator suficiente. O resultado é uma tipologia passível de ser aperfeiçoada e replicada em diferentes contextos, contribuindo tanto para a ampliação do debate acerca do papel do Legislativo no grau de institucionalização de instituições participativas quanto para o aprimoramento dessa agenda de pesquisa.

Esta análise privilegia o papel político do OP, opção equivalente a dizer que, ao voltarmos o nosso olhar para a dimensão estatal, com foco nas instituições e nos atores políticos locais, estamos decididamente lançando luz sobre determinada vertente das relações de mútua constituição entre Estado e sociedade civil, na qual essa instituição participativa finca as suas raízes e se consolida. Não se trata de atenuar a fortaleza do papel da sociedade civil nessa interação, mas, antes, de iluminar os aspectos menos teorizados pela literatura correspondente. Em geral, a dimensão política é equivocadamente observada por meio da "vontade política" de adotar o OP, por parte do prefeito e do respectivo partido. Ademais, as variáveis institucionais são geralmente analisadas de modo apenas parcial, na medida em que esse debate contempla, sobretudo, a metodologia do processo participativo inerente ao OP. Em contrapartida, argumentamos

\footnotetext{
8 É importante aqui sublinhar, nos casos citados, a constatação de variações nos padrões das relações entre prefeitos, vereadores e partidos constituintes do governo, mantidas nas arenas governamental e legislativa. A nosso ver, essa variabilidade contribui para a explicação dos diferentes níveis de durabilidade, assim como dos distintos graus de institucionalização do OP.
} 
que o desenho institucional do OP vai além das suas regras internas de funcionamento, uma vez que sua adoção não anula os outros mecanismos tradicionais existentes, no âmbito municipal, para tomada de decisões, e tampouco extingue as disputas inerentes às instituições formais de representação política.

Este artigo contém quatro seções. Em "O papel dos partidos, governo e Legislativo na literatura brasileira sobre o OP: limites e possibilidades", retomamos brevemente a literatura voltada para as relações entre o OP, o Executivo e o Legislativo, visando evidenciarmos respectivamente os limites e as possibilidades, assim como para corroborarmos o enquadramento analítico adotado. Após esse sobrevoo da produção teórica correlata, expomos, em "O 'desenho institucional' como explicação da 'vontade política'", o desenho da pesquisa, delineando-o segundo uma tipologia composta por quatro dimensões analíticas: 1. Partidos/Prefeito e 2. Partidos/Legislativo versus 3. Durabilidade e 4. Tipos de OP. Em seguida, em "O alcance da composição de forças dos partidos, no Executivo e no Legislativo, no grau de institucionalização do OP", apresentamos o resultado da análise dos seis municípios selecionados que tiveram experiências de Orçamento Participativo (OP) nas gestões municipais de 1997 a 2016 . Por fim, recapitulamos as principais conclusões desta análise e apontamos os desafios mais relevantes da agenda de pesquisa em "À guisa de conclusão".

\section{O papel dos partidos, governo e Legislativo na literatura brasileira sobre o OP: limites e possibilidades ${ }^{9}$}

Os estudiosos sobre os casos de OP no Brasil acompanharam o seu nascimento, apogeu e declínio, ao longo de três gerações de estudos, que se distinguiram pela progressiva incorporação do papel das instituições e dos atores políticos locais entre os seus argumentos predominantes ${ }^{10}$.

Os estudos reunidos na primeira geração se preocuparam mais com os efeitos democráticos do OP. Entretanto, após algumas experiências fracassadas, o debate começou a focar, com maior ênfase, os principais condicionantes que explicavam a adoção, a continuidade e, em menor medida, a interrupção do OP, uma vez que poucos trabalhos analisaram a sua efetividade ${ }^{11}$. Entre os argumentos predominantes, destacaram-se: a "vontade política" do prefeito, a influência do "desenho institucional" e a existência de uma

\footnotetext{
${ }^{9}$ Vale destacar a existência de muitos estudos que investigam a incorporação de mecanismos participativos no Legislativo, sobretudo, concernentes à Assembleia Legislativa do Estado de Minas Gerais (seminários legislativos, fóruns técnicos, ciclos de debates, conferências estaduais e audiências públicas), e os efeitos dessa integração no processo legislativo e nas ações governamentais. Contudo, esses trabalhos não se inserem no escopo desta análise, restrita às instituições participativas adotadas pelo Executivo, tais como o OP. Nessa esfera de produção teórica, recomendamos, por exemplo, a leitura do volume organizado por Oliveira (2009), especialmente os artigos de Fleury e Anastasia.

10 Para um maior aprofundamento desse debate, consultar Souza (2016).

11 O debate sobre a efetividade do OP circunscreve-se ao estudo de Marquetti, Campos e Pires (2008). Para um melhor entendimento sobre a questão da efetividade de instituições participativas, consultar o volume organizado por Pires (2011).
} 
forte "tradição associativa" local (Lüchmann, 2002; Avritzer, 2003; Wampler, 2003; Borba e Lüchmann, 2007). Em geral, os estudos examinaram essas três variáveis combinadas com as características sociais e políticas próprias do universo estudado, incluindo especialmente a capacidade administrativa e financeira dos municípios para implementar as deliberações do OP, as divergências no interior do Executivo, assim como as suas relações com o Legislativo.

Por fim, a discussão sobre a dimensão político-partidária ganhou proeminência no debate sobre os casos brasileiros de OP entre os estudos inscritos na terceira geração. Esses estudos começaram a explorar as relações políticas do OP com as instituições e os atores políticos locais, tanto em suas dinâmicas internas, ou seja, em suas relações com os atores da sociedade civil (que participam do OP), o governo e os partidos políticos (Gurza Lavalle, Houtzager e Acharya, 2004; Romão, 2011), como em suas relações com o OP, o Executivo, o Legislativo, os partidos e as lideranças políticas locais nas diferentes arenas da competição política (Dias, 2000; Souza, 2011). Em relação aos condicionantes, o foco passa a ser gradualmente a interrupção, o abandono ou a adoção do OP por outros partidos, diferentes do PT (Avritzer, 2009; Wampler, 2008; Souza, 2011; Spada, 2014).

A precursora da análise das relações entre o OP, o Executivo e o Legislativo foi Dias (2000). Segundo a autora, "pensar a relação Executivo-Legislativo, a partir da criação do OP, implica avaliar a distribuição dos recursos políticos entre os poderes mencionados" (p. 68). Dias comparou o comportamento do Legislativo a partir do seu grau de intervenção nos projetos de lei originados no Executivo, notadamente em relação às decisões orçamentárias tomadas nos três primeiros mandatos do PT em Porto Alegre (de 1989 a 2000). Resultante dessa análise comparativa, emergiu a identificação de três efeitos do OP sobre a Câmara Municipal: o constrangimento, a renúncia e a reação:

O constrangimento dos vereadores foi causado pela participação popular no processo orçamentário municipal, gerando um conflito de competências simbólico entre a Câmara e o OP. A renúncia dos vereadores apresentou-se como uma consequência do constrangimento; em virtude da intervenção direta da população na distribuição dos recursos para investimentos, o Legislativo passou a esquivar-se de sua principal prerrogativa nas decisões orçamentárias: apresentar emendas para a definição de obras a serem realizadas na cidade. Já a reação dos vereadores ocorreu em virtude do reconhecimento do declínio de seu poder decisório na arena orçamentária. A reação, portanto, consiste em estratégias da oposição legislativa no sentido da recuperação de sua capacidade decisória, ou seja, de resgatar a oportunidade de representar os interesses do seu eleitorado através da incorporação de suas demandas à planilha orçamentária (Dias, 2000, p. 73).

Nesse estudo, a autora argumenta que o OP se constituiu em uma forma de o Executivo se sobrepor ao Legislativo, em virtude de os vereadores se sentirem inicialmente constrangidos em emendar as propostas apresentadas pelo Executivo, com o aval do OP, 
renunciando, assim, ao respectivo poder de veto. No entanto, Dias observa que progressivamente os vereadores passaram a reagir e a traçar uma estratégia de desvincular o OP do PT, buscando institucionalizar essa proposta e visando enrijecer os respectivos mecanismos de funcionamento a fim de inviabilizá-los.

Segundo a autora, apesar de sempre ter sido majoritária na Câmara Municipal, a oposição não logrou frear o avanço da legitimidade conferida ao OP e, tampouco, conseguiu atenuar a política de inversão de prioridades conduzida pelo PT, cuja notável repercussão na comunidade é atestada pela longa hegemonia do partido na administração de Porto Alegre, mantida graças a quatro vitórias eleitorais consecutivas. A autora aponta igualmente o constante crescimento da bancada legislativa petista, inclusive, mediante a incorporação de delegados e conselheiros oriundos do OP ${ }^{12}$.

Embora os resultados apresentados pela tese de Dias (2000) sejam importantes e, até os dias atuais, apresentem considerável impacto na literatura correspondente, nota-se que a autora se limita ao emblemático caso de Porto Alegre, o que deixa em aberto os desdobramentos dessas reações nas diferentes situações confrontadas pela instituição participativa: há casos de continuidade, interrupção e fim da realização do OP, entre grupos políticos aliados ou não ao PT, tal como suscitado em nosso escopo de análise.

Nos estudos posteriores, observa-se que a composição de forças dos partidos no Legislativo, ainda que não se encontre entre os principais mecanismos passíveis de explicar a adoção e a durabilidade do OP, paulatinamente surgiu como um problema a ser mais bem investigado. Esse é notadamente o caso do trabalho de Borba e Lüchmann (2007), em que os autores, ao compararem o desempenho de quatro experiências de OP desenvolvidas no estado de Santa Catarina, mediante a sofisticação das três variáveis usuais empregadas pela literatura (compromisso governamental, desenho institucional e tradição associativa), atentam para alguns fatores críticos e igualmente passíveis de influenciar a longevidade dessa instituição participativa. Um deles seria o processo de esvaziamento gradual do OP ao longo do segundo e do terceiro mandatos do governo, em razão da mudança do prefeito, das alterações nas coligações partidárias ou das diferentes composições na base de apoio governamental no Legislativo. Nessa trilha, os autores já evidenciam a importância da amplitude de uma coalizão governamental como um dos mecanismos ditados pela lógica eleitoral, junto da garantia da reeleição para o segundo mandato - estado de coisas que tendencialmente prejudicaria o desenvolvimento do OP.

Entre as análises que apontam as relações entre o Executivo e o Legislativo como subfator que afetaria o OP, destaca-se o estudo de Wampler (2008). O autor aborda a questão dos interesses políticos dos governantes para explicar as variações nos resultados do OP, aliando-os à capacidade de as organizações da sociedade civil se valerem de

12 "Um fenômeno que vem se destacando na dinâmica eleitoral de Porto Alegre é o da transformação de conselheiros e delegados do Orçamento Participativo em vereadores no município. Esses membros do OP alcançam popularidade em seu trabalho com as comunidades das quais fazem parte, representando suas demandas e transformando-as em medidas práticas incorporadas ao orçamento do munícipio. É esta popularidade que os leva à conquista dos votos necessários para chegar ao Legislativo Municipal" (Dias, 2000, p. 14). 
políticas contestatórias dentro e fora da instituição participativa. Além dessas duas variáveis, Wampler sublinha três outros subfatores suplementares que afetariam os resultados do $\mathrm{OP}$, incluindo as relações entre o Executivo e o Legislativo, as regras internas do OP, bem como a capacidade de investimento do município. Segundo o autor, as relações entre o Executivo e o Legislativo apresentariam grande potencial de influenciar os resultados do OP, ao passo que a ausência de maioria estável poderia debilitar o desenvolvimento dessas instituições participativas (Wampler, 2008, p. 69). No entanto, o autor não se aprofunda na análise dos impactos dessas relações na variabilidade dos resultados do OP, o que nos propomos fazer neste artigo.

Por fim, Spada (2014) desperta a atenção, entre outras questões relevantes, para o progressivo número de cidades que viriam a abandonar o OP, constituindo-se como um dos estudiosos pioneiros nessa temática ${ }^{13}$. O autor verificou que o número de municípios renunciantes ao OP subiu de quatro para 66, entre os anos de 1989 e 1992, nas cidades brasileiras com mais de 50 mil habitantes. Entre as hipóteses do autor, ressalta-se a vulnerabilidade política dos governos das cidades em questão, avaliada por meio da proporção de votos do partido do prefeito, assim como do nível de controle do prefeito sobre o Legislativo (porcentagem de cadeiras do partido do prefeito no Legislativo). Spada conclui que a oposição no Legislativo se desdobraria no abandono do OP, mas não influenciaria a sua adoção ${ }^{14}$.

Ante o exposto, verifica-se a existência de um hiato na literatura sobre o OP, lacuna para cuja superação o presente esforço analítico almeja contribuir. Esse vácuo resulta da ausência de associação sistemática das relações entre os prefeitos, os vereadores e os partidos políticos no âmbito do processo de adoção, continuidade, interrupção e fim do OP, nas múltiplas arenas da competição política, além de inexistir, até onde sabemos, estudo sistemático dos efeitos de tais relações na capacidade de essa instituição participativa se institucionalizar, isto é, ampliar a sua base de apoio graças à pluralização de instâncias participativas em nível governamental e no seio da sociedade civil.

\section{O "desenho institucional" como explicação da "vontade política"}

Embora existam registros significativos de participação no orçamento local anteriores à Constituição de 1988, a adoção do OP e de outras iniciativas participativas na esfera dos orçamentos municipais foi viabilizada pelo novo arranjo constitucional introdutor da possibilidade de controle social nos processos decisórios e relativos à implementação de políticas públicas ${ }^{15}$.

A Constituição de 1988 devolveu a autonomia política municipal, ao definir

\footnotetext{
13 Além de Nylen (2003), Souza (2010, 2011), Goldfrank (2006) e, mais recentemente, Bezerra (2017).

14 Spada (2014) analisa somente a porcentagem de cadeiras do partido do prefeito no Legislativo, e não a proporção de todos os partidos da coligação vencedora, tal como proposto neste artigo, o que eventualmente poderia modificar as respectivas conclusões.

15 Sobre experiências participativas precursoras do OP, ver: Ribeiro e Grazia (2003), Souza (2001), Pires (2001), Baiocchi (2003), entre outros.
} 
os municípios como membros da Federação e ao estabelecer como sendo da competência das cidades e dos respectivos legisladores a elaboração do seu próprio ordenamento político-administrativo, até então de competência estadual. A nova Constituição prevê ainda a participação da sociedade nos processos decisórios municipais, tanto por meio da "cooperação das associações representativas no planejamento municipal" quanto por meio de projetos de lei de iniciativa popular (Pralon e Ferreira, 1998, p. 74-75).

Dadas as novas prerrogativas institucionais, cabe ao governo municipal a iniciativa de criar e incentivar a participação da sociedade por intermédio da adoção do OP ou de outra proposta participativa similar, o que dependeria, segundo parte da discussão inerente à literatura anteriormente apresentada, entre outros fatores, da "vontade política" dos prefeitos, ou seja, da decisão do Executivo associada ao ideário políticopartidário correlato, o qual traduziria o tipo de participação, bem como o sentido das políticas e programas orientados.

No entanto, verifica-se que a instituição do OP está inserida no arcabouço institucional por meio da dinâmica de elaboração orçamentária municipal, a qual, além de ser um instrumento de gestão urbana, é um instrumento político, na justa medida em que a sua aprovação envolve as relações desenvolvidas no âmbito municipal entre os principais atores políticos. Assim sendo, a adoção do OP em governos locais, por exemplo, não altera os trâmites institucionais pelos quais o processo orçamentário se desenvolve, aqui incluído o parecer do Legislativo em várias etapas dessa negociação.

Por conseguinte, o processo de elaboração orçamentária, com ou sem participação social, compreende as seguintes etapas ${ }^{16}$ :

A primeira etapa consiste na elaboração do Plano Plurianual (PPA) ${ }^{17}$ e da Lei de Diretrizes Orçamentárias $(\mathrm{LDO})^{18}$, que definem as diretrizes para o planejamento da prefeitura, as quais, por sua vez, constituem exigências constitucionais. Essas leis são prerrogativas do Executivo e devem ser aprovadas pelo Legislativo Municipal, obedecendo aos prazos e requisitos estabelecidos pela Lei Orgânica do Município ${ }^{19}$ (Pires, 2001, p. 98-103).

A segunda etapa consiste na elaboração do orçamento propriamente dito, contendo a previsão de receitas e despesas, a definição da política tributária e financeira,

\footnotetext{
16 Esse processo intervém em prazo de um ano e, durante esse período, ocorrem diversas emendas e remanejamentos de verbas, sobretudo, em virtude das alterações na arrecadação referentes às receitas municipais.

17 Lei que estabelece, de forma regionalizada, as diretrizes, os objetivos e as metas da administração pública, tendo vigência por período de quatro anos, passando a vigorar a partir do segundo exercício financeiro do mandato do governante, e incidente até o primeiro exercício do governo subsequente (Pires, 2001).

${ }^{18}$ Lei que precede o orçamento, definindo as diretrizes gerais para sua elaboração (Pires, 2001, p. 23). "A LOA estima as receitas e fixa as despesas governamentais para o exercício financeiro subsequente e deve estar em consonância com a LDO e o PPA. No Brasil, a Constituição Federal de 1988 estabeleceu que a LOA compreenderá o orçamento fiscal referente ao Poderes Executivo, Legislativo e Judiciário, seus fundos, órgãos e entidades da administração direta e indireta, inclusive, fundações instituídas ou mantidas pelo Poder Público" (Machado, 2004, p. 14).

19 Segundo Pires, essa lei orgânica "é a constituição do município" (Pires, 2001, p. 23).
} 
a estruturação de programas e projetos de investimentos etc. Após a conclusão do projeto de lei, o orçamento deve ser obrigatoriamente encaminhado para aprovação na Câmara de Vereadores, até o dia 30 de setembro de cada ano, sendo assim submetido aos trâmites legislativos (análise pelas comissões, discussão em plenário, sugestão de votação de emendas e deliberação) antes da sua aprovação (Pires, 2001, p. 98-103)20.

Por fim, o projeto de lei orçamentária aprovado é executado no ano subsequente, sob fiscalização do Legislativo, que atua no sentido de decidir sobre as propostas de alteração feitas pelo Executivo. Além disso, findo o exercício, as contas do governo são apreciadas pelo Tribunal de Contas estadual, o qual emite parecer pela respectiva aprovação ou reprovação. Esse parecer é apreciado pelos vereadores, sendo aprovado ou rejeitado. Quando as contas não são aprovadas, os responsáveis pela execução orçamentária respondem pelas consequências correlatas, o que pode, inclusive, envolver a cassação do mandato do prefeito (Pires, 2001, p. 98-103).

Adicionalmente, é importante salientar a instituição de novos constrangimentos fiscais que impactaram o processo decisório local, tais como a Lei de Responsabilidade Fiscal (LRF) - em vigor desde 2000 e que consolida um regime fiscal responsável, abrangendo os três níveis de governo - associada à Lei Camata, de 1995 (imposição de limites aos gastos com pessoal), à Lei no 9496/97 (refinanciamento das dívidas dos estados) e à Resolução no $78 / 98$ do Senado Federal (imposição de limites ao endividamento de estados e municípios) (Machado, 2004, p. 44). De acordo com os artigos 48 e 49 da LRF, a administração municipal deve incentivar a participação popular na discussão de planos e orçamentos, informar a população com clareza sobre como ocorre o gasto do dinheiro público e publicar as suas contas de forma simples e acessível facilmente a todos os cidadãos.

Desse modo, argumentamos que o desenho institucional do OP vai além das suas regras de funcionamento, tendo em vista que essa instituição participativa está inserida no processo decisório municipal, mas não anula os outros mecanismos tradicionais para a tomada de decisões, existentes na esfera local, e tampouco elimina as disputas políticas próprias às instituições formais de representação política. Portanto, a "vontade política" dos prefeitos de adotar o OP e dar continuidade a ele nas administrações municipais não depende unicamente da respectiva veleidade e das aspirações programáticas do seu partido político, estando igualmente atrelada ao arcabouço institucional regulador das relações entre as instituições e os atores políticos locais, nas múltiplas arenas da competição política. Tais relações serão a seguir compiladas, por intermédio da análise sistemática e diacrônica da composição de forças dos partidos governistas e oposicionistas, traçadas no âmbito da arena eleitoral e incidentes no grau de institucionalização do OP.

\footnotetext{
20 O novo arranjo federativo, resultante da Constituição, fortaleceu o Poder Legislativo na medida em que este assumiu novas competências, tais como a possibilidade de introduzir emendas ao orçamento. Além disso, "foram eliminados alguns dispositivos que constituíam uma interferência na função legislativa do Parlamento, como o 'decurso de prazo' e o 'decreto-lei'"' (Pralon e Ferreira, 1998, p. 75).
} 


\section{O alcance da composição de forças dos partidos, no Executivo e no Legislativo, no grau de institucionalização do OP}

No presente artigo, analisamos três pares contrafactuais de municípios (São Carlos e Piracicaba, Matão e Sertãozinho, Rio Claro e Leme), selecionados por adotarem experiências de OP durante as cinco gestões analisadas (de 1997 a 2016) ${ }^{21}$. Ademais, esses municípios compartilham algumas características comuns, tais como o tamanho (de pequeno a médio porte) ${ }^{22}$, o elevado grau de urbanização ${ }^{23}$, a localização regional (o interior do estado de São Paulo) e a ausência de tradição associativa significativa) ${ }^{24}$. Consequentemente, cada um dos três pares se distingue em virtude do partido do prefeito (PT e outros partidos) e dos graus de institucionalização produzidos pelo OP. Há casos de continuidade por três gestões (participativo), de interrupção dessas experiências entre uma gestão e outra (bifurcado), bem como de finalização após uma ou duas gestões (limitado), como é possível visualizar de modo sintético na Tabela 1:

\section{Tabela 1}

Municípios selecionados em função do partido do prefeito e dos tipos de OP (1997-2016)

\begin{tabular}{|c|c|c|c|c|c|c|}
\hline \multirow{2}{*}{ unicípios } & \multicolumn{5}{|c|}{$\begin{array}{c}\text { Gestões municipais em função do partido do prefeito e da } \\
\text { implantação de OP }\end{array}$} & \multirow{2}{*}{ Tipos de OP } \\
\hline & $1997-2000$ & 2001-2004 & 2005-2008 & $2009-2012$ & $2013-2016$ & \\
\hline São Carlos & PFL & PT (OP) & PT (OP) & PT (OP) & PSDB & \multirow{2}{*}{ Participativo } \\
\hline Piracicaba & PSDB & PT (OP) & PSDB (OP) & PSDB (OP) & PSDB (OP) & \\
\hline Rio Claro & PV-PT (OP) & PV-PT (OP) & PFL & $\begin{array}{l}\text { PMDB-PT } \\
\text { (OP) }\end{array}$ & DEM & \multirow{2}{*}{ Bifurcado } \\
\hline Leme & PSDB (OP) & PFL & PTB* (OC) & DEM (OC) & PT & \\
\hline Matão & PT (OP) & PMDB & PT & PT & PT & \multirow{2}{*}{ Limitado } \\
\hline Sertãozinho & PPB & PSDB (OP) & PSDB (OP) & PPS & PSDB (OP) & \\
\hline
\end{tabular}

Fonte: Elaboração própria a partir de dados da Fundação Seade e do TRE.

(*) Retomada do OP em Leme com a denominação "Orçamento Comunitário".

Desde logo, o objetivo reside em examinar sistematicamente a abrangência das disputas entre os prefeitos, os vereadores e os partidos, aqui reduzidas ao mecanismo institucional delineado pela lógica eleitoral e relacionado às composições de força dos partidos governistas e oposicionistas, no intuito de avaliarmos o respectivo impacto no

${ }^{21}$ A estratégia de comparação entre pares contrafactuais é um método de análise política que se distingue do estudo de caso e de análises quantitativas de $n$ elevado. Embora seja uma metodologia associada à análise qualitativa, ela proporciona uma combinação balanceada entre profundidade descritiva e desafios analíticos que progressivamente declinam quanto mais casos forem adicionados (Tarrow, 2010).

22 População estimada (em habitantes), em 2011, segundo Pesquisa Perfil Municipal da Fundação Seade: São Carlos: 224.228; Piracicaba: 328.029; Rio Claro: 188.019; Leme: 92.041; Matão: 77.270; e Sertãozinho: 111.612 .

23 Taxa de urbanização (em porcentagem), em 2010, segundo Instituto Geográfico e Cartográfico, secretaria de Desenvolvimento Regional e Planejamento do Estado de São Paulo: São Carlos: 95,99; Piracicaba: 97,85; Rio Claro: 97,57; Leme: 97,94; Matão: 98,17; e Sertãozinho: 98,92.

24 Entretanto, no transcorrer da pesquisa, verificamos que um dos casos analisados, o município de Piracicaba, inicialmente selecionado por ser uma experiência de OP que teve continuidade com o PSDB, tinha histórico de tradição associativa. 
grau de institucionalização do OP ou nos tipos de OP adotados, mediante observação diacrônica das cinco gestões municipais de 1997 a 2016.

Dessa forma, o desenho da pesquisa orientou-se pelo foco em dois principais desafios metodológicos. O primeiro, tal como Baiocchi, Heller e Silva (2011, p. 59-60) bem assinalaram, consistiu em irmos além da capacidade de generalização limitada, própria aos estudos de caso predominantes na literatura recente sobre o OP. Esses estudos geralmente sublinham experiências de sucesso desenvolvidas em cidades com características excepcionais, as quais dificilmente podem ter os seus efeitos estendidos para outros contextos. O segundo desafio reconhece que, embora a capacidade de generalização deste artigo tenha se restringido aos ambientes políticos característicos das regiões selecionadas do interior do estado de São Paulo, tal alcance é passível de estender-se no intuito de serem levantadas novas hipóteses acerca da adoção e do grau de institucionalização do OP em cenários semelhantes próprios a grande parte dos municípios brasileiros que adotaram o OP. Segundo Avritzer (2006, p. 623), após o sucesso da experiência na capital gaúcha, O OP se difundiu e alcançou 170 cidades brasileiras no ano de 2005. Contudo, diferentemente da experiência de Porto Alegre, grande parcela dos municípios promotores do OP nesse período equivalia a cidades de pequeno a médio porte, com fraca tradição associativa e localizadas, sobretudo, nas regiões Sul e Sudeste do país. Além disso, quase metade dessas novas experiências esteve ligada ao PT, enquanto a outra parte esteve associada a outros partidos.

Para a análise das "composições de forças dos partidos no governo e na oposição", foram levantadas informações eleitorais do Tribunal Superior Eleitoral (<www.tse.jus.br >), da Fundação Seade - Sistema Estadual de Análise de Dados (<www.seade.gov.br>) e dos websites das Câmaras Municipais dos seis municípios analisados, sendo esses dados relativos ao período compreendido entre 1997 e 2016.

A análise preliminar das informações eleitorais possibilitou a elaboração dos quadros com a "Composição partidária das Câmaras Municipais" (ver Anexos, Quadros de 1 a 6) e dos gráficos "Composição de forças do governo versus oposição" (Gráficos de 1 a 7), os quais serão apresentados ao longo do artigo e se referem aos seis municípios analisados no período entre 1997 e 2016. O período coletado nos sistemas oficiais de informações (TSE/Seade) se restringe às gestões de 2001 a 2016, pois não estão disponíveis informações acerca das coligações referentes às eleições municipais de 1996. Além disso, foram realizadas 30 entrevistas complementares com prefeitos, secretários, vereadores (eleitos por três ou mais mandatos) ${ }^{25}$, coordenadores e funcionários do OP atuantes nos seis municípios selecionados ${ }^{26}$. Essas fontes nos permitiram coletar informações específicas sobre cada caso, assim como elucidar possíveis hipóteses

\footnotetext{
25 Esse quantitativo variou conforme a capacidade de renovação do Legislativo local, assim como a aceitação e a disponibilidade para a realização de entrevistas. A análise das entrevistas revela distintos perfis de vereadores e Câmaras Municipais com relação à participação, além de observarmos trocas frequentes de partidos em todos os casos.

${ }^{26}$ As entrevistas estão disponíveis no site do Cesop, em Revista Opinião Pública, ao final da página do artigo: <https://www.cesop.unicamp.br/por/opiniao_publica/artigo/681>.
} 
explicativas sobre os tipos de OP limitados, examinados nos municípios de Matão e Sertãozinho27.

Com efeito, os dados empíricos levantados permitiram a sofisticação do desenho da pesquisa, a partir da elaboração de uma tipologia composta por quatro dimensões analíticas: A. Partidos/Prefeito, subdividida em A.1. Tipos de Coligação (PT cabeça de chapa, PT na coligação e outro partido) e A.2. Durabilidade do OP (continuidade intragestão com partidos da mesma coligação ou com mais partidos aliados, continuidade intergestões com partidos de coligações diferentes, interrupção intragestão com partidos da mesma coligação ou com mais partidos aliados, interrupção intergestões diferentes e fim do OP); B. Partidos/Legislativo, comportando B.1. Tipos de composição de forças dos partidos no Legislativo (minoria, empate, maioria apertada, maioria frouxa e maioria absoluta) ${ }^{28}$; e C. OP, incluindo C.1 Tipos de OP, os quais se distinguem segundo os respectivos graus de institucionalização, a saber, Participativo, Bifurcado e Limitado, e se subdividem entre forte e fraco 29 .

27 As informações eleitorais organizadas por municípios, assim como a relação de entrevistados, estão disponíveis nos Anexos.

28 A classificação concernente à "composição de forças no Legislativo", empregada nesta análise, não reflete os conceitos dos estudos específicos inerentes à literatura voltada para o Legislativo. Ela se inspirou na linguagem nativa utilizada pelos vereadores dos municípios pesquisados, observada durante as entrevistas e incorporada como categoria de análise.

${ }^{29}$ Assim sendo, consideram-se: um OP forte, quando os programas, gerados a partir de reuniões informativas e deliberativas regionais regulares, elegeram um conjunto de prioridades, diretamente ou por intermédio de representantes, e estabeleceram um conselho com representantes da população e/ou organizações da sociedade civil; um OP fraco, se as experiências não tiverem cumprido os requisitos mencionados, tendo sido realizadas por meio de questionários online, pesquisas em escolas etc., de caráter meramente consultivo. 


\section{Quadro 1 \\ Síntese da tipologia: Partidos/Executivo, Partidos/Legislativo versus Durabilidade e Tipo de OP}

\begin{tabular}{|c|c|c|}
\hline \multicolumn{3}{|c|}{ Dimensões da Análise } \\
\hline A. Partidos/Executivo & $\begin{array}{l}\text { A.1. Tipos de } \\
\text { Coligação } \\
\text { A.1.1. PT (cabeça de } \\
\text { chapa) } \\
\text { A.1.2. PT na } \\
\text { coligação } \\
\text { A.1.3. Outro partido }\end{array}$ & $\begin{array}{l}\text { A.2. Durabilidade do OP } \\
\text { A.2.1. Continuidade intragestão: } \\
\text { mesma coligação (A.2.1.1), com mais } \\
\text { partidos aliados (A.2.1.2) } \\
\text { A.2.2. Continuidade intergestões: } \\
\text { (partidos e/ou coligações diferentes) } \\
\text { A.2.3. Interrupção intragestão: } \\
\text { mesma coligação (A.2.3.1), com mais } \\
\text { partidos aliados (A.2.3.2) } \\
\text { A.2.4. Interrupção intergestão } \\
\text { (partidos e/ou coligações diferentes) } \\
\text { A.2.5. Fim do OP }\end{array}$ \\
\hline B. Partidos/Legislativo & \multicolumn{2}{|c|}{$\begin{array}{l}\text { B.1. Tipos de composição de forças dos partidos no } \\
\text { Legislativo } \\
\text { B.1.1. Minoria (<50\%) } \\
\text { B.1.2. Empate ( } 50 \%) \\
\text { B.1.3. Maioria apertada }(50 \% \text { a } 55 \%) \\
\text { B.1.4. Maioria frouxa }(56 \% \text { a } 60 \%) \\
\text { B.1.5. Maioria folgada }(60 \% \text { a } 74 \%) \\
\text { B.1.6. Maioria absoluta ( }>\text { ou }=\text { a } 75 \%)\end{array}$} \\
\hline C. OP & $\begin{array}{l}\text { C.1. Tipos de OP (gr } \\
\text { C.1.1. Participativo: } \\
\text { Fraco (C.1.1.2) } \\
\text { C.1.2. Bifurcado: Fo } \\
\text { Fraco (C.1.2.2) } \\
\text { C.1.3. Limitado: Fort } \\
\text { Fraco (C.1.3.2) }\end{array}$ & $\begin{array}{l}\text { us de institucionalização) } \\
\text { Forte (C.1.1.1) } \\
\text { (C.1.2.1) } \\
\text { (C.1.3.1) }\end{array}$ \\
\hline
\end{tabular}

Fonte: Elaboração própria.

O grau de institucionalização do OP (o participativo, o bifurcado e o limitado) consiste em uma tipologia ideal desenvolvida com base na incidência de variáveis que orbitam a durabilidade e o alcance qualitativo desta proposta ${ }^{30}$, passível adicionalmente de variar entre forte e fraco ao longo das gestões analisadas. As experiências de OP denominadas participativas têm continuidade em ao menos três gestões e se tornam mais abrangentes, ou seja, apresentam maior alcance em virtude de possibilitarem a criação de dispositivos para a institucionalização desse processo participativo e incentivarem a ampliação dos mecanismos de transparência e dos canais de comunicação entre a administração e a população. No que tange à sociedade, observamos ainda o crescimento das redes associativas do município. As experiências bifurcadas de OP, por sua vez, têm alcance mais restrito, em razão de atravessarem momentos de interrupção e, como resultante, não conseguirem se institucionalizar no município. Outros mecanismos de

30 São elas: respectiva durabilidade; institucionalização da proposta participativa; adoção de outros mecanismos de transparência na gestão municipal; introdução de outros canais formais de comunicação entre a administração e a população; elevação numérica dos conselhos setoriais e conselhos gestores eventualmente existentes; e crescimento quantitativo das associações presentes no município no nível da sociedade. 
comunicação e transparência do governo se encontram em fase embrionária, e as redes da sociedade civil não se proliferaram significativamente. Quanto às experiências de OP limitadas, elas se caracterizam essencialmente pelo fim dessa proposta e/ou pela substituição do OP por fóruns mais regulados, de caráter consultivo e com atuação em parceria com organizações da sociedade civil. Nesse caso, é baixo o nível de institucionalização de outras instituições participativas e canais de comunicação do governo, assim como aquele das organizações da sociedade civil.

\section{Análise da comparação entre os três pares de municípios}

Nesta subseção, apresentamos os resultados da tipologia visando examinar o alcance dos mecanismos institucionais de composição de forças, no governo e na oposição, no tocante à durabilidade e aos tipos de OP, adotados pelo PT, seus aliados e outros partidos (PSDB e PTB), nas gestões de 1997 a 2016, tal como é possível visualizar de modo sintético no Quadro 2:

\section{Quadro 2}

Análise dos municípios e gestões selecionados segundo tipologia: tipos de coligação (A.1), composições de forças dos partidos no Legislativo (A.2), durabilidade (B.1) e tipos de OPs (C.1)

\begin{tabular}{|c|c|c|c|c|c|c|}
\hline \multirow{2}{*}{ Municípios } & \multicolumn{5}{|c|}{$\begin{array}{c}\text { Gestões municipais segundo os tipos de coligação (A.1) } \\
\text { e as composições de forças dos partidos no Legislativo } \\
\text { (B.1) }\end{array}$} & \multirow{2}{*}{$\begin{array}{l}\text { Durabilidade } \\
\text { (A.2) / Tipos } \\
\text { de OP (C.1) }\end{array}$} \\
\hline & $\begin{array}{l}\text { 1997- } \\
\text { 2000* }\end{array}$ & $\begin{array}{c}2001- \\
2004 \\
\end{array}$ & $\begin{array}{c}2005- \\
2008 \\
\end{array}$ & $\begin{array}{c}2009- \\
2012 \\
\end{array}$ & $\begin{array}{l}2013- \\
2016 \\
\end{array}$ & \\
\hline São Carlos & A. 1.3 & $\begin{array}{l}\text { A.1.1 } \\
\text { B.1.1 } \\
\end{array}$ & $\begin{array}{l}\text { A.1.1 } \\
\text { B.1.3 } \\
\end{array}$ & $\begin{array}{l}\text { A.1.1 } \\
\text { B.1.3 } \\
\end{array}$ & $\begin{array}{l}\text { A.1.3 } \\
\text { B.1.1 } \\
\end{array}$ & $\begin{array}{l}\text { A.2.1.1 } \\
\text { C.1.1.1 }\end{array}$ \\
\hline Piracicaba & A.1.3 & $\begin{array}{l}\text { A.1.1 } \\
\text { B. } 1.1 \\
\end{array}$ & $\begin{array}{l}\text { A.1.3 } \\
\text { B. } 1.1\end{array}$ & $\begin{array}{l}\text { A.1.3 } \\
\text { B.1.6 }\end{array}$ & $\begin{array}{l}\text { A.1.3 } \\
\text { B.1.6 }\end{array}$ & $\begin{array}{c}\text { A.2.2 } \\
\text { C.1.1.1 }\end{array}$ \\
\hline Rio Claro & $\begin{array}{l}\text { A. } 1.2 \\
\text { B. } 1.1 \\
\end{array}$ & $\begin{array}{l}\text { A.1.2 } \\
\text { B. } 1.1 \\
\end{array}$ & $\begin{array}{l}\text { A.1.3 } \\
\text { B.1.4 }\end{array}$ & $\begin{array}{l}\text { A.1.2 } \\
\text { B.1.1 }\end{array}$ & $\begin{array}{l}\text { A. } 1.2 \\
\text { B. } 1.2\end{array}$ & $\begin{array}{c}\text { A.2.4 } \\
\text { C.1.2.2 }\end{array}$ \\
\hline Leme & $\begin{array}{l}\text { A.1.3 } \\
\text { B.1.1 } \\
\end{array}$ & $\begin{array}{l}\text { A.1.3 } \\
\text { B. } 1.1 \\
\end{array}$ & $\begin{array}{l}\text { A.1.3 } \\
\text { B.1.4 } \\
\end{array}$ & $\begin{array}{l}\text { A.1.3 } \\
\text { B. } 1.5 \\
\end{array}$ & $\begin{array}{l}\text { A.1.3 } \\
\text { B. } 1.6 \\
\end{array}$ & $\begin{array}{l}\text { A.2.5 } \\
\text { C.1.3 }\end{array}$ \\
\hline Matão & $\begin{array}{l}\text { A.1.1 } \\
\text { B. } 1.1\end{array}$ & $\begin{array}{l}\text { A.1.3 } \\
\text { B. } 1.5 \\
\end{array}$ & $\begin{array}{l}\text { A.1.1 } \\
\text { B. } 1.2 \\
\end{array}$ & $\begin{array}{l}\text { A.1.1 } \\
\text { B.1.4 }\end{array}$ & $\begin{array}{l}\text { A.1.1 } \\
\text { B.1.3 }\end{array}$ & $\begin{array}{l}\text { A.2.5 } \\
\text { C. } 1.4 \\
\end{array}$ \\
\hline Sertãozinho & A. 1.3 & $\begin{array}{l}\text { A.1.3 } \\
\text { B. } 1.4\end{array}$ & $\begin{array}{l}\text { A.1.3 } \\
\text { B.1.5 }\end{array}$ & $\begin{array}{l}\text { A.1.3 } \\
\text { B.1.5 }\end{array}$ & $\begin{array}{l}\text { A.1.3 } \\
\text { B.1.4 }\end{array}$ & $\begin{array}{c}\text { A.2.3 } \\
\text { C. } 1.2 .2\end{array}$ \\
\hline
\end{tabular}

Fonte: Elaboração própria.

* Não há informações oficiais disponíveis acerca das coligações. A análise desse período se baseia na chapa do prefeito e vice-prefeito, bem como nas informações coletadas por meio das entrevistas.

\section{São Carlos e Piracicaba}

Os casos de São Carlos e Piracicaba foram selecionados por terem OPs de tipo Participativo que tiveram continuidade intragestão ao longo de três gestões, tendo sido 
desenvolvidos, respectivamente, pelo PT cabeça de chapa (2001-2012) e por outro partido, nesse caso o PSDB (2005-2016).

Nota-se que o OP de Piracicaba provém de uma continuidade intergestão, ou seja, entre uma gestão do PT (2001-2004) e outra sucessiva do PSDB (2005-2016). Ademais, diferentemente dos outros pares, nos quais a variável "tradição associativa" foi isolada, aqui a situação é mais complexa. Enquanto o município de São Carlos não apresenta significativa tradição associativa, observa-se que o caso de Piracicaba se distingue igualmente pela cultura participativa advinda dos movimentos sociais que despontaram no limiar dos anos 1970, por meio dos trabalhos comunitários da Igreja Católica, assim como por ter vivenciado precocemente uma abertura para a participação da sociedade civil na gestão pública local ${ }^{31}$.

No caso de São Carlos, o OP foi adotado no primeiro mandato do governo petista, o qual rompeu com oligarquias locais dominantes de longa data, e teve continuidade intragestão pela mesma coligação, com mais partidos aliados e por três mandatos consecutivos. Vimos que, na recente história política desse município, predominou o conservadorismo, e tanto o OP quanto o PT constituíram inovações políticas para a cidade.

O município de Piracicaba, por sua vez, foi marcado por gestões antagônicas, envolvendo conservadorismo e progressismo (Silva, 2006, p. 77). Ainda no período de transição democrática, a gestão do prefeito do MDB João Herrmann Neto (1977-1982) foi palco de uma experiência participativa predecessora do OP, conhecida como Planejamento Participativo, e que estimulou precocemente a participação da Federação das Organizações Populares de Piracicaba (Fopop) ${ }^{32}$.

O OP foi implantado em Piracicaba no primeiro ciclo de governos do PT, entre 1989 e 1992, mas foi interrompido nos oitos anos consecutivos de governo do PSDB (19932000). Essa instituição participativa renasceu forte no segundo mandato do PT à frente da prefeitura de Piracicaba (2001-2004) e teve continuidade intergestão, nas três administrações posteriores do PSDB analisadas (2005-2016), ainda que em coligações diferentes.

Em São Carlos, ao analisarmos as composições da base de apoio ao governo no Legislativo, especialmente nas três gestões petistas que adotaram o OP (2001-2012), observamos deslocamentos expressivos, conforme podemos notar no Gráfico $1 . \mathrm{Na}$ primeira gestão, com o PT na cabeça de chapa e a adoção do OP (2001-2004), observamos que a bancada governista detinha minoria parlamentar, ou seja, aproximadamente $19 \%$ das cadeiras, contra os superiores $81 \%$ da oposição. Os conflitos entre o OP e os prefeitos, os vereadores e os partidos foram intensos, resultando em um acordo acerca da capacidade decisória do orçamento no que diz respeito aos investimentos públicos

\footnotetext{
${ }^{31} \mathrm{Na}$ época do estudo, não foi possível encontrar no interior do estado de São Paulo uma experiência de OP com continuidade por mais de três gestões, envolvendo partido diferente do PT e em município que não tivesse grau elevado de tradição associativa. Isso demonstra a efetividade do debate promovido pela literatura correspondente e concernente à força do argumento da tradição associativa, como fator relevante para a continuidade dessa proposta, em gestões em que o partido não é o PT ou seus aliados convencionais. 32 Para uma compreensão mais aprofundada do OP no município de Piracicaba, consultar Silva (2006).
} 
municipais, com a inclusão das "emendas por vereador" a partir do segundo ano do primeiro mandato da agremiação política petista ${ }^{33}$. Assim sendo, cada vereador passou a ter um volume de recursos para formular a sua emenda individual, independentemente de ser da situação ou da oposição, e o OP continuou fortalecido no município ${ }^{34}$.

\section{Gráfico 1}

Composição de forças do governo versus da oposição, no município de São Carlos, no transcorrer das legislaturas de 2001 a 2016 (\%)

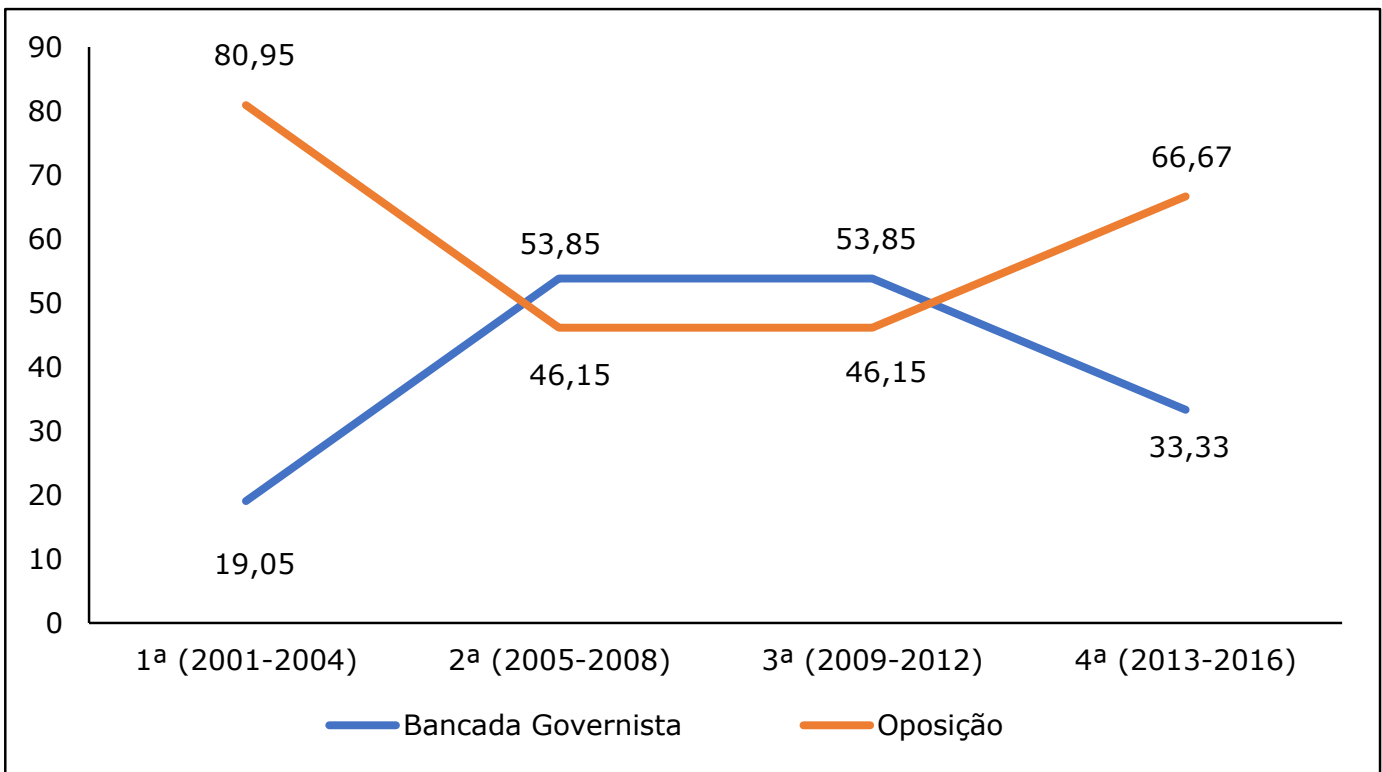

Fonte: Elaboração própria a partir de dados da Fundação Seade, do TRE e da Câmara Municipal de São Carlos.

No segundo e terceiro mandatos, observamos a progressiva incorporação pelo PT de outros partidos políticos, integrados ao seu rol de alianças políticas, além do seu tradicional aliado PCdoB, com especial destaque para PMDB, PDT e PTB, assim como para os "nanicos" PTN, PSC, PR, PRP e PTC. Nesse sentido, o mecanismo ditado pela lógica eleitoral logrou prover à coligação encabeçada pelo PT uma base de apoio com maioria apertada, a saber, cerca de $54 \%$ do total das cadeiras no Legislativo, em ambos os pleitos, condição majoritária paulatinamente ampliada no decorrer do mandato, graças a negociações envolvendo participação/cargos no governo. O OP manteve-se fortalecido como prioridade de governo, entretanto, embora institucionalizado graças à sua inserção no organograma do município, a gestão subsequente do PSDB (2013-2016) ocupou os

\footnotetext{
33 No caso de Piracicaba, observamos, graças às entrevistas, que foram igualmente instituídas as emendas parlamentares, muito embora não tenhamos conseguido rastrear "quando" e "como" isso começou.

34 Essa nova modalidade de cooperação continuou no governo do PSDB (2013-2016) e está se disseminando nos municípios paulistas (com ou sem o OP).
} 
cargos comissionados na coordenação do OP, mas não realizou nenhum tipo de reunião nos bairros com caráter participativo similar ao $\mathrm{OP}^{35}$.

Em Piracicaba, as informações eleitorais sobre a composição de forças no governo e na oposição, no transcorrer das gestões municipais de 2001 a 2016, podem ser visualizadas no Gráfico 2:

Gráfico 2

Composição de forças do governo versus da oposição, no município de Piracicaba, no transcorrer das legislaturas de 2001 a 2016 (\%)

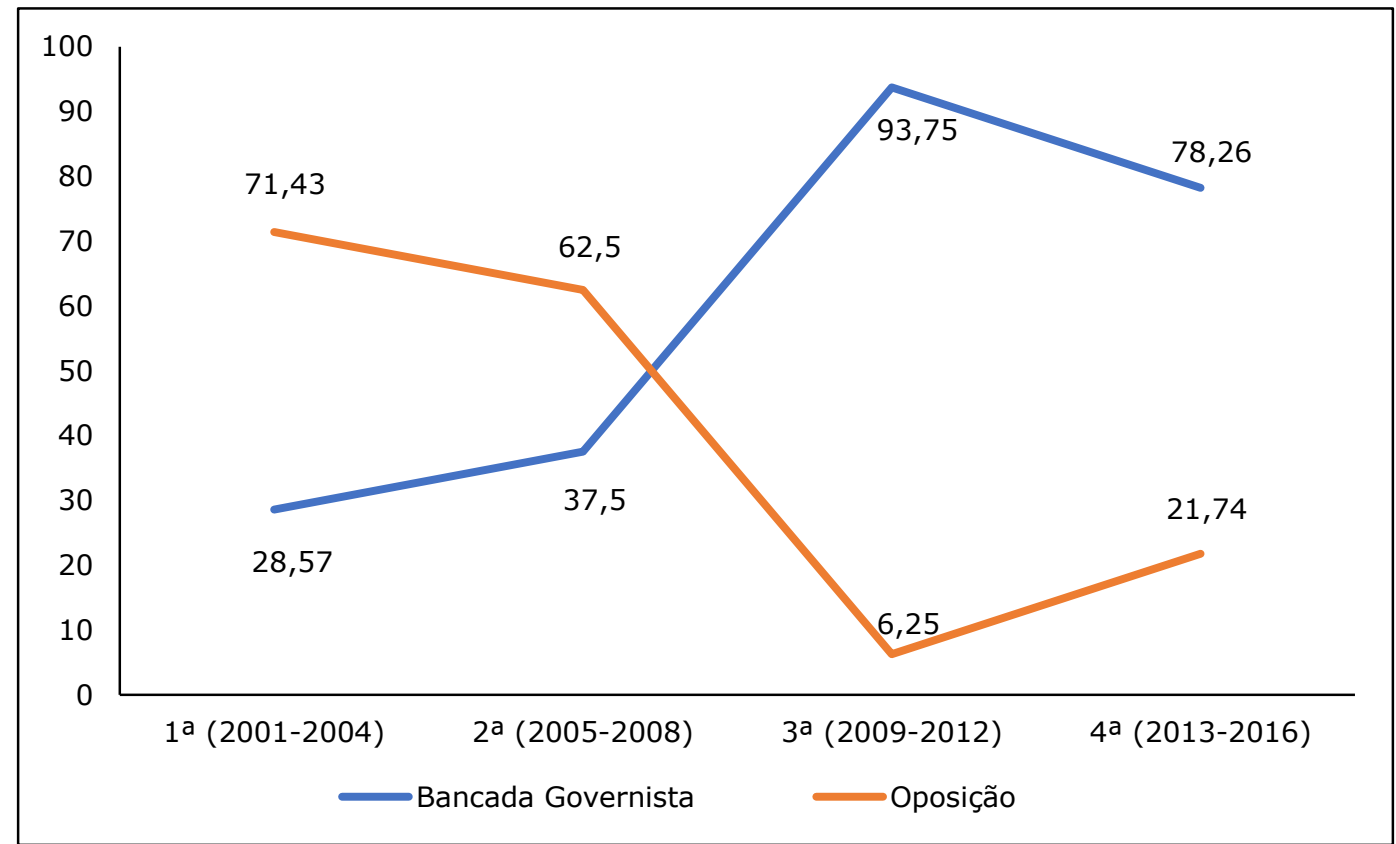

Fonte: Elaboração própria a partir de dados da Fundação Seade, do TRE e da Câmara Municipal de Piracicaba.

Encabeçada pelo PT, a primeira gestão retomou o OP anteriormente adotado no primeiro ciclo petista (1989-1992), que, segundo Silva (2006), foi marcado pela implacável oposição do Legislativo (o PT dispunha de apenas quatro vereadores em um universo de 21). Nota-se que a oposição no Legislativo permaneceu alta, mas a legenda petista demonstrou maior amadurecimento político no segundo mandato: "No campo da governabilidade, o segundo mandato, além de estabelecer uma melhor relação com a Câmara de Vereadores, buscou melhorar a comunicação com os setores da imprensa e com a classe média, por exemplo" (Silva, 2006, p. 112.). O governo do PSDB derrotou o PT após quatro anos e se manteve no poder ao longo dos três últimos mandatos analisados,

35 O OP são-carlense foi institucionalizado por projeto de lei do Legislativo, antes de ser efetivamente adotado. E isso ocorreu no período governado pelo PT e os seus aliados, em virtude da Reforma Administrativa que instituiu a Coordenação do Orçamento Participativo no organograma do Executivo, estando assim ligada ao Gabinete do prefeito. 
ampliando significativamente a sua bancada governista no Legislativo, dando continuidade ao OP e abrindo outros canais permanentes de diálogo entre o gabinete do prefeito e a sociedade civil organizada.

Desse modo, ao compararmos os municípios de São Carlos e Piracicaba, observamos que o OP, em ambas as cidades, foi adotado pelo PT em situação de minoria no Legislativo. Nas duas cidades, O OP teve continuidade intragestão, embora em Piracicaba tenha havido um deslocamento anterior intergestões (PT e PSDB), igualmente impactado pela tradição associativa existente na cidade. No caso de São Carlos, a mesma coligação com o PT como cabeça de chapa se manteve no poder, ampliando progressivamente a sua composição com outras agremiações, até alcançar maioria apertada, que passou a exigir negociações constantes ao longo do governo. Em Piracicaba, o OP continuou com uma coligação com o PSDB, partido que permaneceu no poder por mais três mandatos e igualmente ampliou progressivamente a sua bancada governista no Legislativo. Nesse último caso, à conquista da estabilidade no Legislativo somou-se a fortaleza da sociedade civil, como fatores passíveis de terem contribuído para a continuidade do OP, inter e intragestão, caracterizado como participativo forte.

\section{Rio Claro e Leme}

Os municípios de Rio Claro e Leme foram selecionados como tipos de OPs Bifurcados, isto é, com períodos de interrupção intergestões na adoção da instituição participativa. Além de ambos terem sido adotados com características predominantemente fortes - no caso de Rio Claro, por uma coligação PV-PT e, no caso de Leme, pelo PSDB -, eles foram igualmente retomados por outros partidos/coligações de forma mais atenuada (OP fraco).

A trajetória política de Rio Claro foi marcada pelo predomínio de grupos políticos conservadores. Em 1996, foi eleita uma chapa composta por candidatos progressistas, a prefeito do PV e a vice-prefeito do PT, rompendo com o predomínio de oligarquias políticas até então dominantes. O OP foi adotado no segundo ano do primeiro mandato dessa coligação e permaneceu por duas gestões (1997-2004); foi interrompido por uma gestão contrária a essa proposta participativa (PFL/2005-2008), tendo sido retomado sob outro formato, mais consultivo, em uma nova aliança, encabeçada pela agremiação peemedebista PMDB-PT (2009-2012).

Ao observarmos a composição de forças no governo e na oposição do município de Rio Claro a partir da gestão 2001-2004, exposta no Gráfico 3 - ressalvando-se o fato de não dispormos de informações eleitorais suficientes para o período anterior -, verificamos que o segundo mandato petista sofreu forte oposição no Legislativo, cabendo então aos opositores cerca de $63,16 \%$ das cadeiras. Esse estado de coisas gerou progressivo enfraquecimento do OP, retomado na terceira gestão com uma coligação distinta: PMDB e PT. Nessa administração, o OP teve caráter predominantemente consultivo e a situação com o Legislativo tornou-se mais confortável, marcada por maioria frouxa $(58,33 \%)$. 


\section{Gráfico 3}

\section{Composição de forças do governo versus da oposição, no município de Rio Claro, no transcorrer das legislaturas de 2001 a 2016 (\%)}

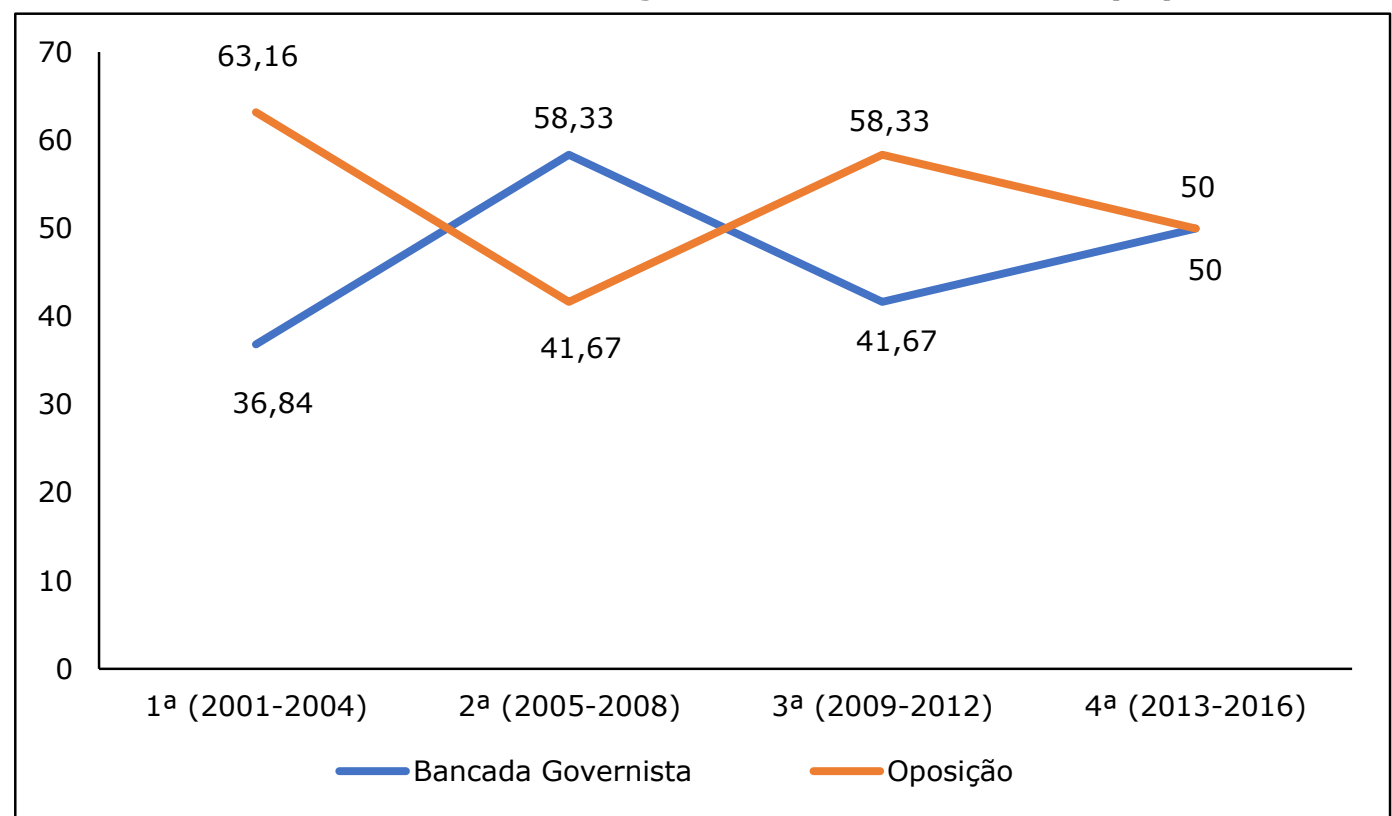

Fonte: Elaboração própria a partir de dados da Fundação Seade, do TRE e da Câmara Municipal de Rio Claro.

No município de Leme, o OP foi adotado pelo PSDB (1997-2000) e não teve continuidade na gestão subsequente ( $P F L)$, mas foi retomado nas gestões seguintes do PTB e DEM (2005-2012) com a denominação "Orçamento Comunitário", em formato consultivo e de caráter fraco, segundo a nossa tipologia. A implementação do OP nesse município teve caráter diferente daquela inerente aos outros OPs, na medida em que foi amparada por um convênio com a Universidade Federal de São Carlos (1997-1999), a qual realizou vários diagnósticos técnicos sobre as condições de vida no município e elaborou um plano para instituir o OP com base em experiências municipais brasileiras, marcadas pelo sucesso e em andamento à época, tais como: Porto Alegre, Goiânia, Recife, Belo Horizonte, Betim, Santo André, entre outras cidades ${ }^{36}$.

Nas eleições de 2000, aliado a oito partidos (PP, PDT, PMDB, PL, PPS, PFL, PSB e PV), o PTB ganhou a disputa eleitoral lemense, obtendo $44,5 \%$ dos votos contra $32,3 \%$ da coligação PT-PCdoB e $23,2 \%$ do PSDB. Após quatro anos de hiato, esse grupo político instituiu um programa participativo denominado "Orçamento Comunitário", com metodologia diferente do OP anteriormente adotado. Esse programa perdurou por dois

\footnotetext{
36 A equipe da UFSCar era composta pelos seguintes membros: profa. dra. Ana Cristina Fernandes, na coordenação geral; eng. Kleyferson Porto de Araújo, na coordenação operacional; além de dois estagiários, Lourenço Leme da Costa Júnior e Rogério Veiga Rodrigues.
} 
mandatos, ou seja, apresentou continuidade intergestão com partidos e coligações diferentes. O ciclo 2005-2008 foi então encabeçado pelo DEM, associado aos seus maiores aliados (PRB, PP, PDT, PTB, PMDB, PSC, PR, PPS e PSB). O nível de institucionalização do OP por nós considerado bifurcado deslocou-se igualmente, passando de forte para fraco, pois o "Orçamento Comunitário" consistiu em um formato consultivo online ao qual se opuseram inúmeras críticas, formuladas pelos atores políticos entrevistados, fundamentalmente no tocante à ausência de participação efetiva da população.

No Gráfico 4, podemos observar a composição de forças do governo e da oposição, no âmbito da arena eleitoral e nas quatro legislaturas analisadas:

\section{Gráfico 4}

Composição de forças do governo versus da oposição, no município de Leme, no transcorrer das legislaturas de 2001 a 2016 (\%)

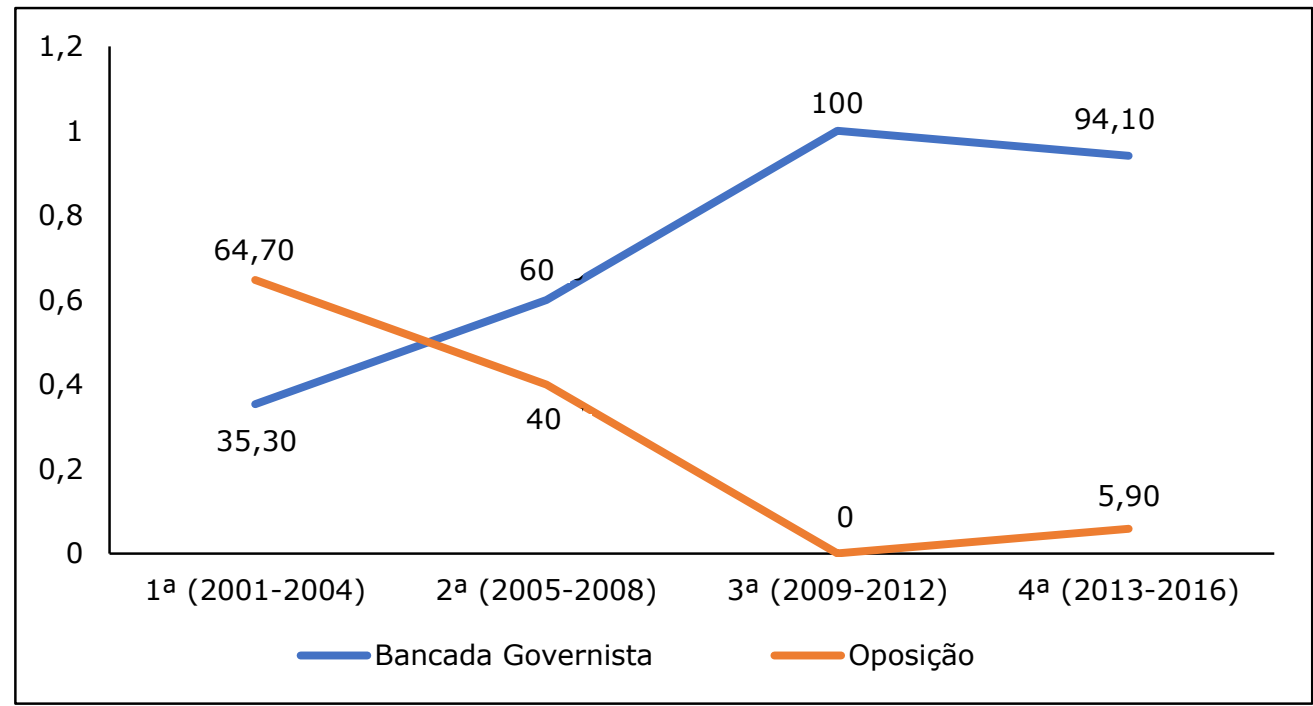

Fonte: Elaboração própria a partir de dados da Fundação Seade, do TRE e da Câmara Municipal de Leme.

No primeiro período exibido no Gráfico 4, não houve OP, pois este último fora adotado na administração anterior (1997-2000), sobre cujas coligações eleitorais não dispomos de informações. Observamos que as duas gestões dotadas de Orçamento Comunitário, respectivamente, a segunda e a terceira do Gráfico 4, apresentaram altos níveis de harmonia com o Legislativo: maioria frouxa $(60 \%)$ e maioria absoluta $(100 \%)^{37}$.

Na última legislatura analisada (2013-2016), houve um acontecimento inesperado e gerador de inúmeros conflitos no seio da política local. O PT passou a ocupar o Executivo no quarto mês desse mandato, após denúncia de fraude eleitoral pelo próprio partido ter sido acatada pelo Tribunal Eleitoral competente. Isso significa que o prefeito (PV), com a sua coligação (PRB, PP, PDT, PTB, PMDB, PSL, PSC, PR, PPS, DEM, PSB, PRP, PSDB, PSD,

37 Nota-se que, nas duas gestões citadas, o número de legisladores igualmente caiu de 16 para 10. 
PCdoB e PTdoB), detentor de esmagadora maioria proporcionada por esse amplo leque de legendas e que ganhara o pleito com 46,24\% dos votos e assumira em janeiro de 2013, teve que se retirar da prefeitura para que o segundo colocado assumisse em abril de 2013 (PT junto do PSDC). A relação entre o Executivo e o Legislativo, em outros mandatos sempre caracterizada por, no mínimo, uma maioria folgada na Câmara, foi permeada por incontáveis conflitos e alguns acordos pontuais, os quais se mostraram muito difíceis de serem mapeados. A título ilustrativo: "em um primeiro momento, votaram contra o Minha Casa Minha Vida, votaram contra numa questão de creches, fizeram um pampeiro" (Entrevistado I). Embora o prefeito do PT se manifestasse abertamente a favor de dar continuidade ao OP, a proposta não seria retomada em sua gestão, interrompida antes do final do mandato, devido a problemas administrativos financeiros potencializados pela situação desfavorável no Legislativo.

Por conseguinte, ao compararmos os municípios de Rio Claro e Leme, observamos que o OP de ambas as cidades foi adotado em situações opostas, tanto em relação ao partido do prefeito quanto à composição do governo e da oposição. O OP de Rio Claro foi adotado pela coligação PT-PV, tendo a legenda petista ficado a cargo da respectiva coordenação durante as duas gestões em que esse grupo político se manteve no poder (intragestão). No caso de Leme, o OP foi adotado pelo PSDB, contando com a colaboração de consultoria técnica especializada, e perdurou por uma única gestão desse partido no poder. Embora não tenhamos informações eleitorais sobre as coligações da gestão 19972000, no caso da coligação PV-PT em Rio Claro, segundo os relatos dos entrevistados houve conflitos com o Legislativo, inclusive, em razão da minoria parlamentar governista na segunda gestão (2001-2004), enquanto, no caso da gestão do PSDB de Leme, averiguamos a existência de maioria governista nesse período. Após um período de interrupção, o OP renasceu em Rio Claro e o Orçamento Comunitário foi adotado em Leme, ambos mais fracos e de caráter consultivo, mas com situações mais confortáveis no Legislativo.

\section{Matão e Sertãozinho}

Os casos de Matão e Sertãozinho, por sua vez, foram selecionados por constituírem casos de OP iniciados pelo PT e pelo PSDB, mas posteriormente abandonados pelos respectivos partidos. No entanto, o OP de Sertãozinho continuou intragestão por dois mandatos e, mais recentemente, foi retomado por iniciativa tanto do Executivo quanto do Legislativo, mas em formato meramente consultivo.

No município de Matão, o OP foi adotado no primeiro mandato do PT (1997-2000), legenda que rompeu com o predomínio de grupos políticos de longa data à frente do governo municipal. Eleito pela primeira vez por uma pequena margem de votos, o PT adotou o OP, tal como ocorrido em São Carlos. Todavia, na eleição para a gestão subsequente, essa legenda seria derrotada pelo PMDB e mais 11 partidos, então reunidos para derrotar o PT e os seus três aliados político-partidários (2005-2008). Esse novo 
agrupamento político retomaria o poder, quatro anos depois, com apoio de mais sete partidos, permanecendo no poder até 2013, sem dar continuidade ao OP.

No Gráfico 5, observamos a composição de forças do governo e da oposição nas cinco gestões analisadas do município de Matão. O OP não se institucionalizou, após quatro anos de OP forte e conflitos com o Legislativo: a bancada governista ocupava apenas 23,5\% das cadeiras. O PT voltou ao poder, após um mandato de interrupção (2001-2004), e permaneceu no governo por três mandatos consecutivos, usufruindo de situação mais confortável no Legislativo (empate, maioria frouxa e maioria apertada); contudo, o OP não teria a mesma sorte nesse município.

\section{Gráfico 5}

Composição de forças do governo versus da oposição, no município de Matão, no transcorrer das legislaturas de 1997 a 2016 (\%)

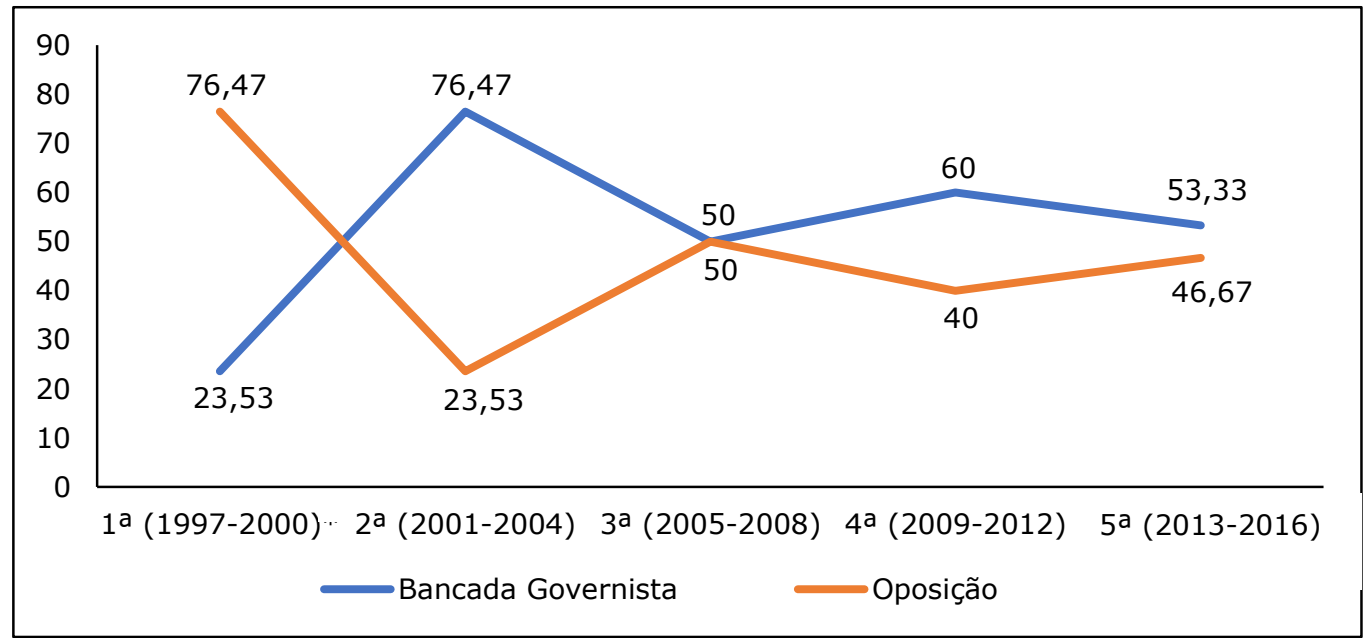

Fonte: Elaboração própria a partir de dados da Fundação Seade, do TRE e da Câmara Municipal de Matão.

Ao longo dos três mandatos, as estratégias de negociação do PT de Matão foram diferentes. A primeira administração, segundo os entrevistados, foi marcada por relações difíceis com a Câmara: o PT teve apoio de apenas cinco vereadores, de um total de 19 representantes eleitos, e eventualmente fazia composição com os demais. Isso conferiu maior centralidade e visibilidade ao Poder Legislativo. Ao passo que, nos segundo e terceiro mandatos, o PT se coligou com outros partidos desde o período eleitoral e incorporou outros aliados no seu rol de alianças durante essas gestões (inclusive DEM e PV). Contudo, durante as entrevistas, os líderes do governo na Câmara relataram que nada foi "engessado", pois houve, por exemplo, projetos do governo não aprovados e que foram consequentemente retirados.

O município de Sertãozinho foi escolhido por ser um caso de OP do PSDB não institucionalizado após duas gestões (2001-2008). Entretanto, essa situação se alterou no transcorrer da pesquisa, uma vez que o OP foi retomado na última gestão (2013-2016) 
analisada, com o apoio dos vereadores. Nota-se que o OP em Sertãozinho constitui igualmente um espaço para o legislador, embora o prefeito sempre desempenhe papel principal nesse cenário. Nesse município, o OP é considerado fraco, pois a sua metodologia se diferencia consideravelmente daquela usualmente adotada. Nas entrevistas, relataramse a divisão da cidade em regiões e a realização de reuniões com a participação de prefeito, vereadores, organizações da sociedade civil convidadas e da população em geral. Todavia, não obtivemos informações substantivas acerca da metodologia e das suas possíveis variações, o que evidencia o seu caráter mais político do que participativo. Ademais, as relações entre o Executivo e o Legislativo se mostraram harmônicas ao longo dos mandatos analisados, variando entre maioria frouxa e folgada por parte do governo, tal como é possível verificar no Gráfico 6:

\section{Gráfico 6}

Composição de forças do governo versus da oposição, no município de Sertãozinho, no transcorrer das legislaturas de 2001 a 2016 (\%)

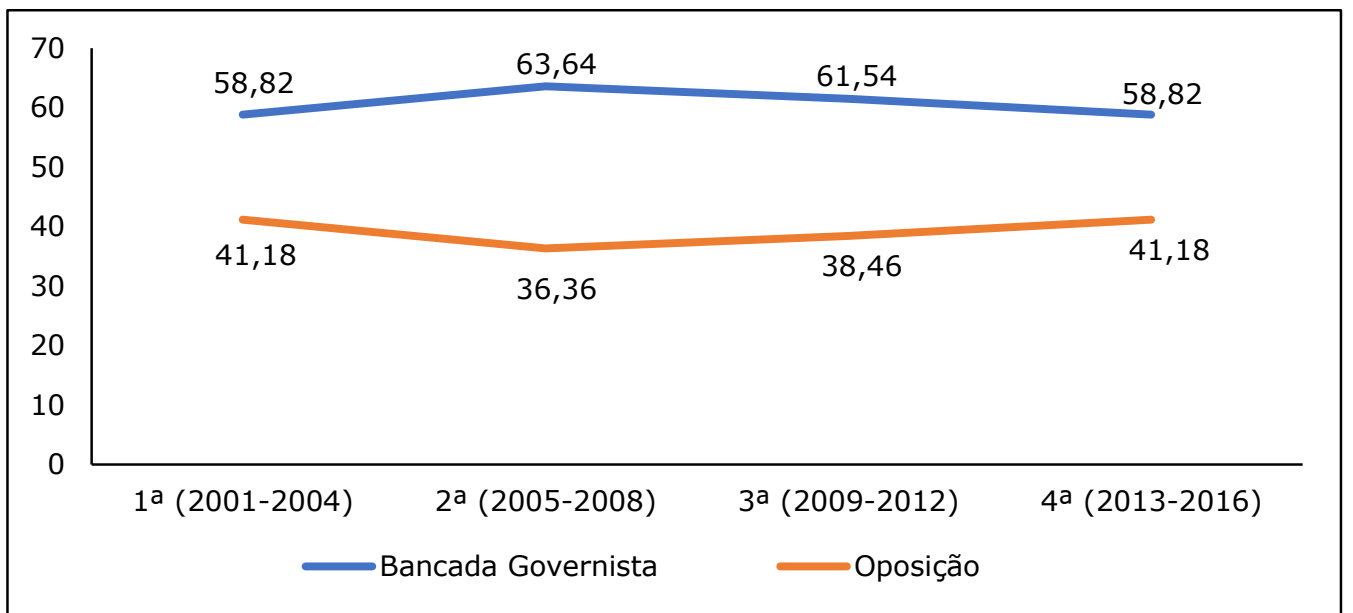

Fonte: Elaboração própria a partir de dados da Fundação Seade, do TRE e da Câmara Municipal de Sertãozinho.

Segundo as entrevistas realizadas, embora haja uma coalizão de governo usufruindo de maioria no Legislativo, os vereadores têm independência para votar contra o governo. A título de exemplo: "O prefeito mandou um projeto do IPTU que teve uma repercussão notória. Na realidade, nós votamos contra o IPTU. O prefeito não gostou, mas ele assimilou e vamos tocando numa harmonia muito boa" (Entrevistado F). Em Sertãozinho, foi igualmente adotada a emenda por vereador, em vigor desde a gestão anterior; mas, diferentemente de São Carlos, os entrevistados, inclusive da oposição, manifestaram-se satisfeitos com esse acordo. Os vereadores se valem desse recurso para destinarem, em benefício de entidades filantrópicas, projetos sociais, campeonatos esportivos ou até mesmo pequenas obras nas regiões mais vulneráveis. 
Dessa forma, notamos que o município de Sertãozinho nos reserva suas peculiaridades. Em primeiro lugar, podemos destacar que os legisladores entrevistados compartilharam uma visão positiva dos espaços participativos, mas reclamaram que poucas pessoas efetivamente participam:

Eu tiro por base uma lei do governo federal em que cada trimestre o prefeito tem que vir na Câmara e fazer uma audiência pública e são chamados o presidente das associações de moradores, a população, todas as entidades. Mas ninguém aparece. $O$ prefeito lota a sessão de todos os secretários e diretores. Vem um ou outro representante da população, mas ela mesma não vem e isso é muito ruim. O povo tem que saber onde está sendo investido o dinheiro, quais são os direcionamentos de seus impostos pagos, mas ele não participa (Entrevistado K).

Em segundo lugar, de acordo com os entrevistados, o OP pode ser encarado como uma ideia do PT a ser aproveitada, como momento para o encontro do prefeito com a vontade popular, algo passível de se tornar importante em qualquer administração e constituinte de uma das possibilidades em meio a um leque de decisões políticas. No caso de Sertãozinho, embora o OP seja um programa de governo desenvolvido pelo Executivo, os vereadores apoiam, participam e identificam vantagens políticas nesse âmbito. Inclusive, um dos vereadores fez recentemente um requerimento solicitando a volta do OP e, segundo um dos entrevistados, todos os vereadores fizeram uso da palavra para manifestarem apoio unânime à aprovação da medida:

O prefeito tem que participar porque às vezes a pessoa não quer pedir nada, quer apenas pegar em sua mão e falar um oi. Ninguém vê o prefeito, ninguém consegue e ele ganha muito com a sua participação junto à população, se aproximando e atendendo algum pedido. $\mathrm{E}$ o vereador idem. $\mathrm{O}$ vereador é a pessoa mais próxima da população (Entrevistado K).

Com a implantação do OP, nós tínhamos reuniões nos bairros, reuniões aqui e acolá e o poder público ia ouvi-los e levava os secretários, os vereadores. Contudo, os orçamentos têm os seus limites, não dava para atender todas aquelas reivindicações e passou a ter um certo descrédito. Agora nós estamos voltando novamente a interagir com a população. Vamos voltar a implantar o Orçamento Participativo, as obras vão ser agregadas ao orçamento, e vamos analisar quais delas podem efetivamente ser cumpridas porque o que desgasta a população é a promessa não cumprida, o descrédito (Entrevistado L).

É um momento de você sentir a reação popular, termômetro do que está acontecendo naquele bairro, naquele setor. Então uma reivindicação que a sociedade vai fazer. O vereador vai aprovar ou não. O vereador vai fiscalizar 
PARTIDOS, GOVERNO E LEGISLATIVO NAS DISPUTAS DO ORÇAMENTO PARTICIPATIVO: UMA ANÁLISE COMPARATIVA

pessoalmente se aquilo que o morador pediu está sendo executado (Entrevistado F).

Ressalvamos também que os vereadores desse município entrevistados apresentam maior clareza no que tange à divisão de papéis no interior do OP, inclusive um deles relatou que essa questão é muito discutida entre eles, com vistas a conseguirem aproveitar o momento de contato com a população das mais diversas formas:

Eu posso correr todo o bairro na véspera e anotar todas as necessidades e levá-las e ser um grande personagem dessa reunião. Mas a estrela que realmente brilha nessas reuniões é a do prefeito. O prefeito que é o dono do dinheiro, pode-se assim dizer, mas você pode servir-se dessa luz, você dá também a sua contribuição. O político não pode perder a oportunidade de falar, é igual advogado, e aproveitar a presença do prefeito e conversar com educação e com elegância: "Senhor prefeito, por uma questão de ordem está faltando isso e aquilo naquele bairro" e usar isso em proveito da comunidade (Entrevistado $\mathrm{M}$ ).

Por fim, assunto recorrente nas entrevistas e cuja incidência em favor do feliz casamento entre o OP e os legisladores é perfeitamente plausível, identificamos a notável ausência de novas lideranças políticas no município. O PSDB vem desde muito tempo governando Sertãozinho, poder exercido na pessoa do último prefeito José Alberto Gimenez. Nas últimas gestões, os partidos aliados acabaram não lançando candidatos próprios no município, inviabilizando, assim, o surgimento de novas lideranças no interior desse grupo político.

\section{À guisa de conclusão}

No presente artigo, analisamos os alcances e eventuais limites do mecanismo institucional de composição de forças do Legislativo, no que diz respeito ao respectivo impacto na durabilidade e no grau de institucionalização das instituições participativas adotadas pelo PT e seus aliados, bem como por outros partidos (PSDB e PTB), em seis municípios examinados aos pares nas administrações entre 1997 e 2016.

Assim sendo, podemos dizer que o OP nasce na arena eleitoral e se viabiliza nas arenas governamental e legislativa. Após analisarmos os mecanismos institucionais para composição de forças do governo no Legislativo, traçados na arena eleitoral, postulamos que, em caso de eventual cooperação entre o Executivo e o Legislativo, o OP apresentou maior nível de institucionalização quando houve coligação com o PT na cabeça de chapa, tal como em São Carlos, revelando-se igualmente participativo e forte nos casos em que subsistiu durante gestões de diferentes partidos, a exemplo de Piracicaba (PT e PSDB). Na hipótese de OPs bifurcados, tanto entre gestões de diferentes coligações com o PT, como ocorreu em Rio Claro, quanto entre gestões de diferentes partidos, caso do PSDB e das 
gestões do PFL/DEM e do PTB, em Leme, verificamos que a situação de disputa ou de harmonia no Legislativo não interferiu significativamente, pois o resultado em ambos os episódios foi o retorno de um OP aquém do esperado. Na eventualidade de OPs limitados, estes abrangem o fim do OP por iniciativa do PT e estando essa legenda em cabeça de chapa, como em Matão, e também em Sertãozinho, com o PSDB. No transcorrer da nossa pesquisa referente a esse último município, constatamos que o $\mathrm{OP}$, ocasionalmente implantado anos antes por duas gestões do PSDB em situação nitidamente confortável no Legislativo, voltou mais recentemente em formato consultivo, com consultas online e impressas, inclusive, a pedido dos vereadores. No caso do fim do OP por iniciativa petista, observamos a ocorrência, concomitante à realização do OP, de intensos conflitos da bancada minoritária petista com a Câmara Municipal.

Ainda que restrita a uma única variável e embora de menor profundidade vis-à-vis aquela levada a cabo nos casos petistas, a comparação com experiências de OPs desenvolvidas por outros partidos revelou que a amplitude da coalizão ou das alianças políticas não se mostra suficiente para conferir continuidade a um OP participativo forte, por iniciativa de outro partido. Diferentemente das oportunidades em que houve coligações petistas inéditas, na qual o OP constituiu poderosa estratégia eleitoral inicial do PT, nesses casos de iniciativas alheias ao petismo, a implantação da instituição participativa foi paulatinamente arrefecida em função da competição política. No caso de Piracicaba, por exemplo, a continuidade intergestões do PT e do PSDB logrou êxito, igualmente, em virtude da tradição associativa das organizações da sociedade civil no município. Em Leme, o OP foi implementado por uma única gestão do PSDB, sendo coordenado por uma equipe técnica especializada durante um momento de notório reconhecimento mundial dessa experiência democrática, na qualidade de boa prática de governança urbana. As relações com o Legislativo, além de marcadas pela presença majoritária do partido governista no parlamento, foram intermediadas por uma equipe técnica que já previra os potenciais conflitos e, consequentemente, apresentava relatórios periódicos aos legisladores. Após um hiato, o OP retomou nas gestões seguintes do PTB e DEM, sendo então denominado "Orçamento Comunitário", em formato baseado em ferramenta consultiva on-line. Em Sertãozinho, o OP pode ser apreciado como forma de o PSDB instituir um espaço de diálogo aberto envolvendo prefeito, secretários municipais, vereadores, associações de bairro e população em geral, todavia sem exclusão de outros canais existentes, como emendas ao orçamento, distribuídas igualmente entre os parlamentares e pactuadas entre o prefeito e os vereadores, independentemente dos seus respectivos partidos serem da oposição ou da situação.

Por um lado, mediante comparação entre os casos petistas, podemos assinalar que, quanto maior foi a centralidade do OP, como estratégia eleitoral desse partido, tanto menor e mais homogênea configurou-se a coligação eleitoral e, eventualmente, tanto mais negociada mostrou-se a formação de coalizão entre partidos governistas e oposicionistas nas arenas governamental e legislativa. Nesse caso, o OP somente perdurou participativo e forte quando a cooperação foi conquistada graças à obtenção de maioria parlamentar 
e/ou em função de outros acordos envolvendo novos desenhos de políticas. Por outro, quanto menor foi a centralidade do OP na arena eleitoral, tanto maior e mais heterogênea configurou-se a coligação eleitoral constituída, estado de coisas que, provavelmente, ampliou as chances de governabilidade e de futuros acordos/alianças entre os partidos, nas arenas governamental e legislativa. Nesse último caso, o nível de institucionalização do OP mostrou-se mais precário, quiçá inexistente. Nos casos de OPs adotados por outros partidos ou quando outros partidos the deram continuidade, sejam eles o PT ou não, existem outras variáveis que impõem exploração mais aprofundada, entre as quais, podemos destacar a influência do próprio nível de tradição associativa e/ou a apropriação do conceito de participação orçamentária de formas diferenciadas pelos gestores de partidos mais conservadores.

Finalizamos ressaltando, em meio aos inúmeros desafios dessa agenda de pesquisa, o imperativo de combinarmos esse tipo de análise, mais focado no papel das instituições e dos atores políticos locais, com perspectivas mais centradas na sociedade civil, no intuito de darmos continuidade ao processo de compreensão dos mecanismos que influenciam a adoção, a durabilidade, a interrupção, o fim e os diferentes graus de institucionalização dessas inovações democráticas do mundo contemporâneo.

\section{Referências bibliográficas}

AVRITZeR, L. O Orçamento Participativo e a teoria democrática: um balanço crítico. In: AVRITZer, L.; NAVARRo, Z. (orgs.). A inovação democrática no Brasil: o Orçamento Participativo. São Paulo: Cortez, 2003.

\footnotetext{
. "New public spheres in Brazil: local democracy and deliberative politics". International Journal of Urban and Regional Research, vol. 30, n 3, p. 623-637, set. 2006. Press, 2009.

. Participatory institutions in democratic Brazil. Baltimore: Johns Hopkins University

BAIOCCHI, G. Radicals in power. In: BAIOCCHI, G. (ed.). Radicals in power: the Worker's Party (PT) and experiments in urban democracy in Brazil. London: Zed Books Ltd, 2003.

BAIOCCHI, G.; HeLLeR, P.; SilvA, M. K. Bootstrapping democracy. Transforming local governance and civil society in Brazil. Stanford: Stanford University Press, 2011.

BezerRa, C. "Por que o Orçamento Participativo entrou em declínio no Brasil? Mudanças na legislação fiscal e seu impacto sobre a estratégia partidária". Anais do $41^{\circ}$ Encontro Annual da Anpocs, Caxambu, MG, 2017. Disponível em: <http://anpocs.com/index.php/encontros/papers/41-encontroanual-da-anpocs/spg-4/spg18-4/10987-por-que-o-orcamento-participativo-entrou-em-declinio-nobrasil-mudancas-na-legislacao-fiscal-e-seu-impacto-sobre-a-estrategia-partidaria/file>. Acesso em: 12 ago. 2020.
}

Borba, J.; LÜChMAnN, L. Capítulo 1. In: Borba, J.; LüCHMANN, L. (orgs.). Orçamento Participativo: uma análise das experiências desenvolvidas em Santa Catarina. Florianópolis: Ed. Insular Ltda., 2007.

DIAS, M. R. "Na encruzilhada da teoria democrática: efeitos do Orçamento Participativo sobre a Câmara Municipal de Porto Alegre". Tese de Doutorado em Ciência Política. Instituto Universitário de Pesquisas do Rio de Janeiro, Universidade Cândido Mendes, Rio de Janeiro, 2000. 
DiAS, N.; EnRÍqueZ, S.; Júlio, S. (orgs.). Atlas mundial dos Orçamentos Participativos. Portugal: Epopeia e Oficina, 2020. Disponível em: <www.oficina.org.pt/atlas>. Acesso em: 12 ago. 2020.

FEDOZZI, L. O eu e os outros: participação e construção da consciência social. Porto Alegre: Tomo, 2008.

GoldFrANK, B. "Los procesos de 'presupuesto participativo' en América Latina: êxito, fracaso y cambio". Revista de Ciencia Política, 2006.

Gurza lavalle, A.; Houtzager, P.; Acharya, A. Lugares e atores da democracia: arranjos institucionais, participação e sociedade civil em São Paulo. In: CoelHo, V. S.; NoBRE, M. (orgs.). Participação e deliberação: teoria democrática e experiências institucionais no Brasil contemporâneo. São Paulo: Ed. 34, 2004.

LÜChMANN, L. H. H. "Possibilidades e limites da democracia deliberativa: a experiência do Orçamento Participativo de Porto Alegre". Tese de Doutorado em Ciências Sociais. Instituto de Filosofia e Ciências Humanas, Universidade de Campinas, Campinas, 2002.

vol. 13, no $28,2014$.

"25 anos de Orçamento Participativo: algumas reflexões analíticas". Política \& Sociedade,

MACHADO, F. T. H. F. "O orçamento público e o planejamento no contexto dos municípios do estado de São Paulo a partir da Lei de Responsabilidade Fiscal". Dissertação de Mestrado em Administração Pública e Governo. Escola de Administração de Empresas de São Paulo, Fundação Getúlio Vargas, São Paulo, 2004.

Marquetti, A.; Campos, G. A.; Pires, R. (orgs.). Democracia participativa e redistribuição: análise de experiências de orçamento participativo. São Paulo: Xamã, 2008.

NYLEN, W. R. An enduring legacy? Popular participation in the aftermath of the participatory budget of João Monlevade and Betim. In: BAIocchI, G. (ed.). Radicals in power: the Worker's Party (PT) and experiments in urban democracy in Brazil. London: Zed Books Ltd., 2003.

Oliveira, M. C. (org.). A Assembleia de Minas e a construção coletiva de políticas públicas: eventos institucionais, 1990-2009. Belo Horizonte: Assembleia Legislativa do Estado de Minas Gerais, 2009.

PIRES, R. R. (org.). Efetividade das instituições participativas no Brasil: estratégias de avaliação. Vol. 7. Brasília, DF: Ipea, 2011.

Pires, V.; Pineda Nebot, C. "Presupuesto participativo: uma tipología para superar los límites de las definiciones demasiado amplias o restrictivas". Reala - Revista de Estudios de la Administratión Local y Autonómia, no 308, p. 207-246, 2008.

PIRES, V. Orçamento Participativo: o que é, para que serve, como se faz. São Paulo: Manole, 2001.

Pralon, E. M.; Ferreira, G. N. Centralidade na Câmara Municipal de São Paulo no Processo Decisório. In: ANDRADE, R. C. (org.). Processo de governo no município e no estado: uma análise a partir de São Paulo. São Paulo: Edusp, 1998.

Ribeiro, A. C. T.; GraziA, G. Experiências de Orçamento Participativo no Brasil: período de 1997 a 2000. São Paulo: Vozes, 2003.

RomÃo, W. M. "O eclipse da sociedade política nos estudos sobre Orçamento Participativo". BIB, São Paulo, no 70, p. 121-144, 2010.

. "Conselheiros do Orçamento Participativo nas franjas da sociedade política". Lua Nova, São Paulo, no 84, p. 353-364, 2011. 
Serafim, L.; TeIXeIrA, A. C. Balanço e desafios para a continuidade do OP - Gestão 2005-2008. In: V Seminário Repensando o Orçamento Participativo. Instituto Pólis/Fórum Paulista de Participação Popular. São Paulo, 2006.

Sintomer, Y.; Herzberg, C.; RöCKE, A. "Participatory budgeting in Europe: potentials and challenges". International Journal of Urban and Regional Research, vol. 32, no 1, p. 164-178, 2008.

"Modelos transnacionais de participação cidadã: o caso do Orçamento Participativo". Sociologias, vol. 14, no 30, p. 70-116, 2012.

Silva, R. G. "Orçamento Participativo: o caso de Piracicaba". Tese de Doutorado em Ciências Sociais. Programa de Pós-Graduação em Ciências Sociais, Pontifícia Universidade Católica, São Paulo, 2006.

SouzA, C. "Construção e consolidação de instituições democráticas: papel do Orçamento Participativo". São Paulo em Perspectiva, vol. 15, no 4, p. 84-97, out.-dez. 2001.

SouzA, L. A. M. "Do local para o nacional: o Orçamento Participativo e as novas práticas políticas petistas". Tese de Doutorado em Ciência Política. Programa de Pós-Graduação em Ciências Sociais, Universidade Federal de São Carlos, São Carlos, 2010.

2011. . "Orçamento Participativo e as novas dinâmicas políticas". Lua Nova, São Paulo, no 84, . "'Virada institucional': o debate sobre o papel das instituições e dos atores nas três gerações de estudos sobre o Orçamento Participativo". BIB, São Paulo, no 79, p. 83-103, 2016.

SPADA, P. "The adoption and abandonment of democratic innovations: investigating the rise and decline of participatory budgeting in Brazil". In: International Congress of the Latin American Studies Association, 32. Chicago, 2014.

TARROW, S. "The strategy of paired comparison: toward a theory of practice". Comparative Politics Studies, vol. 43, no 2, p. 230-259, 2010.

WAMPLER, B. Orçamento Participativo: uma explicação para amplas variações nos resultados. In: Avritzer, L.; NAvarro, Z. (orgs.). A inovação democrática no Brasil: o Orçamento Participativo. São Paulo: Cortez, 2003.

. "When does participatory budgeting deepen the quality of democracy? Lessons from Brazil". Comparative Politics, vol. 41, no 1, p. 61-81, out. 2008. 


\section{Anexos}

Quadro 1

Composição partidária da Câmara Municipal de Leme (de 2001 a 2016)

\begin{tabular}{|c|c|c|c|c|}
\hline \multirow{2}{*}{ Partido } & \multicolumn{4}{|c|}{ Legislaturas } \\
\hline & $1^{a}(2001-2004)$ & $2^{a}(2005-2008)$ & $3^{a}(2009-2012)$ & $4^{a}(2013-2016)$ \\
\hline PFL/DEM & 3 & - & 3 & 2 \\
\hline PPB & 2 & - & - & - \\
\hline PDT & 1 & - & - & - \\
\hline PPS & - & 1 & - & - \\
\hline PV & - & - & - & 5 \\
\hline PSB & 1 & - & 1 & 2 \\
\hline PSDB & 3 & 2 & - & 1 \\
\hline PTB & 3 & 2 & 2 & \\
\hline PMDB & 3 & 1 & 2 & 1 \\
\hline PT & 1 & 2 & - & 1 \\
\hline PP & - & 2 & 1 & \\
\hline PR & - & - & 1 & 1 \\
\hline PSC & - & - & - & 2 \\
\hline PSD & - & - & - & 2 \\
\hline $\begin{array}{l}\text { Bancada } \\
\text { governista (OP) }\end{array}$ & 6 & 6 & 10 & 16 \\
\hline Oposição & 11 & 4 & - & 1 \\
\hline $\begin{array}{l}\text { Total de } \\
\text { Vereadores }\end{array}$ & 17 & 10 & 10 & 17 \\
\hline
\end{tabular}

Fonte: Elaboração própria a partir de dados da Fundação Seade, do TRE e Câmara Municipal de Leme. 
Quadro 2

Composição partidária da Câmara Municipal de Matão (de 1997 a 2016)

\begin{tabular}{|c|c|c|c|c|c|}
\hline \multirow[b]{2}{*}{ Partido } & \multicolumn{5}{|c|}{ Legislaturas } \\
\hline & $\begin{array}{c}1^{\mathrm{a}} \\
(1997-2000)\end{array}$ & $\begin{array}{c}2^{\mathrm{a}} \\
(2001-2004)\end{array}$ & $\begin{array}{c}3^{a} \\
(2005-2008)\end{array}$ & $\begin{array}{c}4^{a} \\
(2009-2012)\end{array}$ & $\begin{array}{c}5^{a} \\
(2013-2016)\end{array}$ \\
\hline PT & 3 & 4 & 3 & 4 & 4 \\
\hline PSDB & 3 & - & 1 & - & 1 \\
\hline PMDB & 3 & 5 & 1 & - & - \\
\hline PSD & 2 & 1 & - & - & - \\
\hline PFL/DEM & 2 & 3 & 2 & - & 1 \\
\hline PPB & 1 & - & - & - & - \\
\hline PTB & 1 & 1 & 1 & - & - \\
\hline PDT & 1 & - & - & 1 & 2 \\
\hline $\mathrm{PL}$ & 1 & - & - & - & - \\
\hline PRP & - & 2 & - & - & - \\
\hline PSB & - & 1 & 2 & 1 & 2 \\
\hline PSDC & - & - & - & 1 & - \\
\hline $\mathrm{PP}$ & - & - & - & 2 & - \\
\hline PPS & - & - & - & 1 & 1 \\
\hline PSL & - & - & - & - & 2 \\
\hline PCdoB & - & - & - & - & 1 \\
\hline PV & - & - & - & - & 1 \\
\hline Bancada Governista & $4(\mathrm{OP})$ & 13 & 5 & 6 & 8 \\
\hline Oposição & 13 & 4 & 5 & 4 & - \\
\hline Total de Vereadores & 17 & 17 & 10 & 10 & 15 \\
\hline
\end{tabular}

Fonte: Elaboração própria a partir de dados da Fundação Seade, do TRE e Câmara Municipal de Matão.

\section{Quadro 3}

Composição partidária da Câmara Municipal de Piracicaba (de 1997 a 2016)

\begin{tabular}{|c|c|c|c|c|c|}
\hline Partido & $\begin{array}{c}1^{\mathrm{a}} \\
\left(1997^{-2000}\right)\end{array}$ & $\begin{array}{c}2^{\mathrm{a}} \\
(2001-2004)\end{array}$ & $\begin{array}{c}3^{a} \\
(2005-2008)\end{array}$ & $\begin{array}{c}4^{\mathrm{a}} \\
(2009-2012)\end{array}$ & $\begin{array}{c}5^{a} \\
(2013-2016)\end{array}$ \\
\hline PSDB & 4 & 4 & 3 & 5 & 6 \\
\hline PPS & 4 & 3 & 4 & 2 & 3 \\
\hline PT & 2 & 5 & 3 & 1 & 2 \\
\hline PMDB & 2 & 2 & 1 & 1 & 1 \\
\hline PFL/DEM & 2 & 1 & 1 & - & - \\
\hline PV & 1 & 1 & - & - & 2 \\
\hline PTB & 2 & 1 & 1 & 1 & 2 \\
\hline PPB & 1 & 2 & - & - & - \\
\hline PDT & 2 & - & 2 & 2 & 3 \\
\hline $\mathrm{PL}$ & 1 & 2 & 1 & - & - \\
\hline PSB & - & - & - & - & - \\
\hline PRB & - & - & - & 1 & 1 \\
\hline $\begin{array}{l}P P \\
\end{array}$ & - & - & - & 1 & 1 \\
\hline PSC & - & - & - & - & 1 \\
\hline PR & - & - & - & 2 & 1 \\
\hline $\begin{array}{l}\text { Bancada } \\
\text { governista }\end{array}$ & Sem informação & 6 & 6 & 1 & 18 \\
\hline Oposição & Sem informação & 15 & 10 & 1 & 5 \\
\hline $\begin{array}{l}\text { Total de } \\
\text { vereadores }\end{array}$ & 21 & 21 & 16 & 16 & 23 \\
\hline
\end{tabular}

Fonte: Elaboração própria a partir de dados da Fundação Seade, do TRE e Câmara Municipal de Piracicaba. 
Quadro 4

Composição partidária da Câmara Municipal de Rio Claro (de 2001 a 2016)

\begin{tabular}{|c|c|c|c|c|c|}
\hline \multirow[b]{2}{*}{ Partido } & \multicolumn{5}{|c|}{ Legislaturas } \\
\hline & $\begin{array}{c}1^{\mathrm{a}} \\
(1997-2000)\end{array}$ & $\begin{array}{c}2^{a} \\
(2001-2004)\end{array}$ & $\begin{array}{c}3^{a} \\
(2005-2008)\end{array}$ & $\begin{array}{c}4^{a} \\
(2009-2012)\end{array}$ & $\begin{array}{c}5^{a} \\
(2013-2016)\end{array}$ \\
\hline PV & - & 3 & - & - & - \\
\hline PT & 2 & 2 & 2 & 2 & 2 \\
\hline PSDB & 2 & 2 & - & - & 1 \\
\hline PRP & 2 & 1 & - & - & 1 \\
\hline PTB & 2 & 3 & 1 & 2 & 1 \\
\hline PDT & 3 & 2 & - & - & 1 \\
\hline PMDB & 3 & 2 & 2 & 3 & 3 \\
\hline $\mathrm{PL}$ & - & 1 & 2 & - & - \\
\hline PPB & 4 & 2 & - & - & - \\
\hline PFL/DEM & 1 & - & 2 & 2 & 2 \\
\hline $\mathrm{PP}$ & - & - & 1 & 1 & 1 \\
\hline PSL & - & - & 1 & - & - \\
\hline PSC & - & - & 1 & - & - \\
\hline PR & - & - & - & 2 & - \\
\hline Bancada governista & Sem informação & 7 & 7 & 5 & 6 \\
\hline Oposição & Sem informação & 11 & 5 & 7 & 6 \\
\hline Total de vereadores & 19 & 19 & 12 & 12 & 12 \\
\hline
\end{tabular}

Fonte: Elaboração própria a partir de dados da Fundação Seade, do TRE e Câmara Municipal de Rio Claro.

Quadro 5

Composição partidária da Câmara Municipal de São Carlos (de 2001 a 2016)

\begin{tabular}{|l|c|c|c|c|}
\hline \multirow{2}{*}{ Partido } & \multicolumn{4}{|c|}{ Legislaturas } \\
\cline { 2 - 5 } & $\begin{array}{c}\mathbf{1}^{\mathbf{a}} \\
\mathbf{( 2 0 0 1 - 2 0 0 4 )}\end{array}$ & $\begin{array}{c}\mathbf{2}^{\mathbf{a}} \\
(\mathbf{2 0 0 5 - 2 0 0 8 )}\end{array}$ & $\begin{array}{c}\mathbf{3}^{\mathbf{a}} \\
(\mathbf{2 0 0 9 - 2 0 1 2 )}\end{array}$ & $\begin{array}{c}\mathbf{4}^{\mathbf{a}} \\
\mathbf{2 0 1 3 - 2 0 1 6 )}\end{array}$ \\
\hline PT & 4 & 2 & 3 & 4 \\
\hline PTB & 3 & - & - & - \\
\hline PPB & 2 & - & - & - \\
\hline PDT & 2 & 2 & 2 & 4 \\
\hline PMDB & 2 & 3 & - & 1 \\
\hline PPS & 1 & 2 & 2 & 1 \\
\hline PFL/DEM & 1 & - & - & - \\
\hline PSD & 2 & - & 3 & 4 \\
\hline PSDB & 2 & 3 & - & - \\
\hline PST & 1 & - & - & - \\
\hline PL & 1 & - & 1 & 1 \\
\hline PV & - & 1 & 1 & 1 \\
\hline PR & - & - & - & 2 \\
\hline PHS & - & - & - & 1 \\
\hline PSC & - & - & 7 & 7 \\
\hline Bancada governista & 4 & 7 & 6 & 14 \\
\hline Oposição & 17 & 6 & 13 & 21 \\
\hline Total de vereadores & 21 & 13 & - & \\
\hline
\end{tabular}

Fonte: Elaboração própria a partir de dados da Fundação Seadee, do TRE e da Câmara Municipal de São Carlos. 
Quadro 6

Composição partidária da Câmara Municipal de Sertãozinho (de 2001 a 2016)

\begin{tabular}{|c|c|c|c|c|}
\hline \multirow[b]{2}{*}{ Partido } & \multicolumn{4}{|c|}{ Legislaturas } \\
\hline & $\begin{array}{c}1^{a} \\
(2001-2004)\end{array}$ & $\begin{array}{c}2^{a} \\
(2005-2008)\end{array}$ & $\begin{array}{c}3^{a} \\
(2009-2012)\end{array}$ & $\begin{array}{c}4^{a} \\
(2013-2016)\end{array}$ \\
\hline PTB & 5 & 3 & 3 & 3 \\
\hline PMDB & 4 & 2 & 1 & 2 \\
\hline PSDB & 1 & 2 & 3 & 3 \\
\hline PPB & 4 & - & - & - \\
\hline PFL & 1 & - & - & - \\
\hline PT & 2 & - & - & - \\
\hline PV & - & 1 & - & - \\
\hline $\mathrm{PL}$ & - & 2 & - & - \\
\hline PDT & - & 1 & 1 & - \\
\hline PSB & - & - & - & 1 \\
\hline PPS & - & - & 3 & 4 \\
\hline PR & - & - & 1 & 2 \\
\hline PSC & - & - & 1 & 2 \\
\hline Bancada governista & 10 & 7 & 8 & 10 \\
\hline Oposição & 7 & 4 & 5 & 7 \\
\hline Total de vereadores & 17 & 11 & 13 & 17 \\
\hline
\end{tabular}

Fonte: Elaboração própria a partir de dados da Fundação Seade, do TRE e da Câmara Municipal de Sertãozinho.

ista das entrevistas realizadas ao longo da pesquisa

\begin{tabular}{|c|c|c|c|c|c|}
\hline N. & Data & Nome & Cargo & Cidade & Partido \\
\hline 01 & 2009 & Ademir de Souza & $\begin{array}{c}\text { Secretário de Bem-Estar Social e } \\
\text { presidente do PT }\end{array}$ & Matão & PT \\
\hline 02 & $22 / 07 / 14$ & $\begin{array}{l}\text { Ademir José } \\
\text { Soldera }\end{array}$ & Vereador & Sertãozinho & PTB \\
\hline 03 & $04 / 08 / 14$ & Agnaldo Navarro & Vereador e Presidente da Câmara & Matão & PDT \\
\hline 04 & $08 / 08 / 14$ & $\begin{array}{l}\text { Antônio Carlos } \\
\text { Catarino }\end{array}$ & Vereador & São Carlos & PTB \\
\hline 05 & $22 / 07 / 14$ & $\begin{array}{c}\text { Antônio Cesar } \\
\text { Peghini }\end{array}$ & Vereador & Sertãozinho & PPS \\
\hline 06 & $04 / 08 / 14$ & $\begin{array}{l}\text { Aparecido do } \\
\text { Carmo de Souza } \\
\text { (Cidinho) }\end{array}$ & Vereador & Matão & PT \\
\hline 07 & $01 / 07 / 15$ & Barjas Negri & $\begin{array}{l}\text { Prefeito, Deputado Federal, } \\
\text { Ministro da Saúde (FHC) }\end{array}$ & Piracicaba & PSDB \\
\hline 08 & $08 / 07 / 15$ & $\begin{array}{c}\text { Carlos Gomes da } \\
\text { Silva }\end{array}$ & Vereador & Piracicaba & PP \\
\hline 09 & $24 / 07 / 15$ & Cláudia & Coordenadora do OP & Leme & $\begin{array}{c}\text { Sem } \\
\text { partido }\end{array}$ \\
\hline 10 & $02 / 07 / 14$ & $\begin{array}{l}\text { Edson Antônio } \\
\text { Fermiano }\end{array}$ & Vereador & São Carlos & PR \\
\hline 11 & $02 / 07 / 14$ & $\begin{array}{c}\text { Equimarcilias de } \\
\text { Souza Freire }\end{array}$ & Vereador & São Carlos & PMDB \\
\hline 12 & $17 / 04 / 14$ & $\begin{array}{c}\text { Géria Maria } \\
\text { Montanar Franco }\end{array}$ & $\begin{array}{l}\text { Presidente do PT (atual), } \\
\text { Vereadora, Secretária da } \\
\text { Educação e Coordenadora do OP } \\
\text { e Relações com a Comunidade }\end{array}$ & São Carlos & PT \\
\hline
\end{tabular}




\begin{tabular}{|c|c|c|c|c|c|}
\hline N. & Data & Nome & Cargo & Cidade & Partido \\
\hline 13 & $16 / 04 / 14$ & $\begin{array}{l}\text { João Carlos } \\
\text { Pedrazzani }\end{array}$ & $\begin{array}{c}\text { Chefe de Gabinete, Secretário de } \\
\text { Governo e Secretário de } \\
\text { Planejamento }\end{array}$ & São Carlos & PT \\
\hline 14 & $27 / 06 / 14$ & $\begin{array}{l}\text { João Marcos } \\
\text { Pinhada }\end{array}$ & Secretário de Governo & Sertãozinho & PSDB \\
\hline 15 & $27 / 06 / 14$ & $\begin{array}{c}\text { José André } \\
\text { Mazer }\end{array}$ & Vereador & Sertãozinho & PTB \\
\hline 16 & $04 / 08 / 14$ & $\begin{array}{l}\text { José Ap. Ferreira } \\
\text { dos Santos }\end{array}$ & Vereador & Matão & PT \\
\hline 17 & $20 / 07 / 15$ & $\begin{array}{l}\text { Juninho da } \\
\text { Padaria/João } \\
\text { Teixeira Junior }\end{array}$ & Vereador & Rio Claro & DEM \\
\hline 18 & $14 / 05 / 15$ & $\begin{array}{c}\text { Kleyferson } \\
\text { Araújo }\end{array}$ & Assessoria Técnica UFSCar & Leme & $\begin{array}{c}\text { Sem } \\
\text { partido }\end{array}$ \\
\hline 19 & $01 / 07 / 14$ & $\begin{array}{c}\text { Laíde das Graças } \\
\text { Simões }\end{array}$ & Vereadora & São Carlos & PMDB \\
\hline 20 & $16 / 04 / 14$ & Lineu Navarro & Vereador & São Carlos & PT \\
\hline 21 & $30 / 06 / 14$ & Marcos Amaral & $\begin{array}{c}\text { Vereador e atual Presidente da } \\
\text { Câmara }\end{array}$ & São Carlos & PSDB \\
\hline 22 & $20 / 07 / 15$ & $\begin{array}{c}\text { Maria do Carmo } \\
\text { Guilherme }\end{array}$ & Vereadora & Rio Claro & PMDB \\
\hline 23 & $14 / 07 / 14$ & $\begin{array}{l}\text { Maria Izabel Ap. } \\
\text { Parolim }\end{array}$ & Vereador & Leme & PT \\
\hline 24 & $22 / 07 / 14$ & $\begin{array}{l}\text { Nério Garcia da } \\
\text { Costa }\end{array}$ & $\begin{array}{c}\text { Ex- Prefeito, Vice-Prefeito, } 3 \\
\text { mandatos como Vereador e atual } \\
\text { Coordenador de Projetos }\end{array}$ & Sertãozinho & PEN \\
\hline 25 & $09 / 05 / 15$ & $\begin{array}{c}\text { Newton Lima } \\
\text { Neto }\end{array}$ & Prefeito, Deputado Federal & São Carlos & PT \\
\hline 26 & 2009 & Olga Salomão & $\begin{array}{c}\text { Vice-prefeita, coordenadora } \\
\text { do OP }\end{array}$ & Rio Claro & PT \\
\hline 27 & $21 / 07 / 14$ & $\begin{array}{c}\text { Paulo Roberto } \\
\text { Blascke }\end{array}$ & Prefeito & Leme & PT \\
\hline 28 & $21 / 07 / 15$ & Raquel Picelli & Vereadora & Rio Claro & PT \\
\hline 29 & 2009 & $\begin{array}{c}\text { Rosoé Francisco } \\
\text { Donato }\end{array}$ & $\begin{array}{l}\text { Coordenador do OP, Secretário de } \\
\text { Planejamento e Gestão e } \\
\text { presidente do PT }\end{array}$ & São Carlos & PT \\
\hline 30 & $22 / 07 / 14$ & Silvio Blancacco & Vereador & Sertãozinho & PSDB \\
\hline
\end{tabular}

Fonte: Elaboração própria a partir das informações levantadas nas entrevistas.

\begin{abstract}
Parties, government and Legislative power in the Participatory Budgeting (PB) disputes: a comparative analysis

This article aims to broaden the debate about the disputes between the PB, the parties and the local political actors, by presenting a systematic and diachronic analysis of the impacts of the balance of power of the governing and opposition parties, outlined within the scope of the electoral arena, on the adoption, interruption, interruption and the end of this democratic innovation, as well as on its different degrees of institutionalization. To this end, we analyzed three counterfactual pairs of municipalities with mostly similar characteristics, namely: São Carlos and Piracicaba; Rio Claro and Leme; Matão and Sertãozinho, which differ from each other by the party that led the PB initiative (PT and other
\end{abstract}


parties). The results reveal a universe little explored and likely to be replicated in other contexts, contributing both to the expansion of the debate on the role of the legislative power in the degree of institutionalization of participatory institutions and to the improvement of this research agenda.

Keywords: Participatory Budgeting (PB); political parties; executive power; legislative power; local governments

\section{Resumen}

Partidos, gobierno y Legislativo en las disputas del Presupuesto Participativo: un análisis comparativo

Este artículo busca ampliar el debate acerca de las disputas entre el PP, los partidos y los actores políticos locales, al presentar un análisis sistemático y diacrónico del impacto de la composición de fuerzas de los partidos en el poder y los de la oposición, perfilada en el ámbito de la arena electoral, así como de la adopción, continuidad, interrupción y fin de esta innovación democrática, en sus distintos grados de institucionalización. Para ello, analizamos tres pares contrafactuales de municipios con características esencialmente similares, a saber: São Carlos y Piracicaba; Rio Claro y Leme; Matão y Sertãozinho, que se diferencian entre sí por el partido que lideró la iniciativa del PP (PT y otros partidos). Los resultados nos revelan un universo poco explorado y susceptible de ser replicado en otros contextos, contribuyendo tanto a la ampliación del debate sobre el papel del Legislativo en el grado de institucionalización de las instituciones participativas, como a la mejora de esta agenda de investigación.

Palabras clave: Presupuesto Participativo (PP); partidos políticos; ejecutivo; legislativo; gobiernos locales

\section{Résumé}

Partis, gouvernement et pouvoir Législatif dans les disputes associées au budget participatif (BP): une analyse comparative

Cet article se destine à élargir le débat ayant trait aux disputes entre le BP, les partis et les acteurs politiques locaux, en présentant une analyse systématique et diachronique des impacts du rapport de forces esquissé dans le cadre de l'arène électorale par les partis au pouvoir et d'opposition, aussi bien quant à l'adoption, la continuité, I'interruption et la fin de cette innovation démocratique, qu'en ce qui concerne les différents degrés d'institutionnalisation respectifs. Pour ce faire, nous avons analysé trois paires contrefactuelles de communes présentant des caractéristiques essentiellement similaires, à savoir : São Carlos et Piracicaba ; Rio Claro et Leme ; Matão et Sertãozinho, qui diffèrent les unes des autres quant au parti ayant dirigé l'initiative du BP (PT et autres partis). Les résultats révèlent un univers peu exploré et susceptible d'être répliqué dans d'autres contextes, contribuant à la fois à l'élargissement du débat sur le rôle du pouvoir législatif dans le degré d'institutionnalisation des institutions participatives et à la consolidation de cette thématique de recherche.

Mots-clés: Budget participatif (BP); partis politiques; pouvoir exécutif; pouvoir législatif; gouvernements locaux

Artigo submetido à publicação em 14 de dezembro de 2018. Artigo ressubmetido à publicação em 12 de agosto de 2020. Versão final aprovada em 14 de janeiro de 2021.

Opinião Pública adota a licença Creative Commons CC-BY.

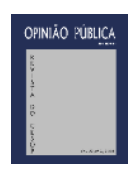

